\title{
COMMENTS
}

\section{MAKING PARENTS PAY: INTERSTATE CHILD SUPPORT ENFORCEMENT AFTER UNITED STATES V. LOPEZ}

\author{
KATHLEEN A. BURDETTE†
}

\section{INTRODUCTION}

When Jeffrey Nichols, a wealthy consultant, decided to divorce his wife of sixteen years in order to marry a younger woman, he was ordered to pay $\$ 9000$ a month in support for his three children. ${ }^{1}$ Believing that the children's grandfather would support them, Nichols ignored his child support obligations and, instead, lived in luxury with his second wife for over five years. ${ }^{2}$ After cleaning out his accounts in New York, where the children and his ex-wife still reside, he moved to Toronto. ${ }^{3}$ In an attempt to evade law enforcement officials who make it their business to search for "deadbeat dads," Nichols then moved to Boca Raton, Florida and later to Vermont. ${ }^{4} \mathrm{He}$ also attempted to conceal some of his assets by placing them in his second wife's name and in offshore accounts that could not be traced. ${ }^{5}$ The law finally caught up with Nichols when his second wife, in the process of filing for divorce, signed an affidavit stating that Nichols had been avoiding child support payments for five years. ${ }^{6}$

Nichols, who spent four months in a New York jail, ${ }^{7}$ owes more

† B.A. 1994, Cornell University; J.D. Candidate 1997, University of Pennsylvania. I would like to thank Professor Seth Kreimer for listening to my ideas at various stages of their development. I am also grateful to my Law Review editors, Pamela Reichlin, Karin Guiduli, and Laura Boschken, for their suggestions. Special thanks to David Shields, who has encouraged me throughout my time at the Law School. This Comment is dedicated to my family, without whose love and support I would not be here.

${ }^{1}$ See Sixty Minutes: Deadbeat Dads (CBS television broadcast, Oct. 29, 1995), available in LEXIS, News Library, Rtvrpt File [hereinafter Sixty Minutes].

${ }^{2}$ See id.

${ }^{3}$ See id.

${ }^{4}$ See id.

5 See Claude Lewis, "Deadbeat Dad" Deserved Detention, Dallas MoRning News, Aug. 24, 1995, at 29A, available in Westlaw, Allnews Database.

'See Sixty Minutes, supra note 1.

${ }^{7}$ See Greg B. Smith, No-Pay Dad Free But Still Owes Big, DaIly News (N.Y.), Feb. 
than half a million dollars in overdue child support payments that he contends he is unable to pay. ${ }^{8}$ While Nichols was "living to the hilt," his ex-wife says that there were "days she didn't know if she'd make it, with 3 kids." ${ }^{n}$ Federal prosecutors, acting under the Child Support Recovery Act of $1992,{ }^{10}$ eventually indicted Nichols. ${ }^{11}$ State prosecutors asked for, and received, a contempt ruling that was to keep Nichols, who is believed to be the nation's largest child support debtor, in jail until he paid at least $\$ 68,000$ of the support money he owes. ${ }^{12}$ Nichols was released after four months, however, because he convinced the judge that he could not liquidate his assets while he was in jail. ${ }^{13}$ Unfortunately, commented Suzanne Colt, a lawyer for New York City who finds deadbeat parents, results like those in the Nichols case, where the delinquent parent is indicted and imprisoned, are still the exception to the rule. ${ }^{14}$

A Michigan judge sentenced another deadbeat dad to serve two to three years in prison for failing to pay a child support obligation that has accumulated to $\$ 140,000$ over the last sixteen years. ${ }^{15}$ Just as Jeffrey Nichols fled the state where his children lived in order to avoid his support obligation, Patrick Law left Michigan less than a month after a support order was entered against him. ${ }^{16}$ Law may also face similar charges in Arizona, "where he abandoned a second wife two years ago."17

The length of time that Nichols, Law, and many others like them have avoided paying child support illustrates the ease with which obligations may be avoided by leaving the state that issued the child support order. Because states are primarily responsible for the enforcement of support orders, ${ }^{18}$ and states' coercive powers are

27,1996 , at 6.

${ }^{8}$ See Sixty Minutes, supra note 1.

${ }^{9}$ Id.

${ }^{10}$ Pub. L. No. 102-521, § 2(a), 106 Stat. 3403, 3403 (codified as amended in scattered sections of 18 U.S.C. and 42 U.S.C.).

${ }^{11}$ See Keep Heat on Deadbeats, PALM BEACH Post, Sept. 5, 1995, at A18.

${ }_{12}$ See Lewis, supra note 5, at 29A; No. 1 Deadbeal Dad: No Ties to Kids, USA TODAY, Oct. 27, 1995, at A3.

${ }^{13}$ See Smith, supra note 7, at 6.

${ }^{14}$ See Sixty Minutes, supra note 1.

${ }^{15}$ See Deadbeat Dad Gets Up to 3 Years in Prison, CHI. TRIB., July 21, 1994, at A3 [hereinafter Deadbeat Dad].

${ }^{16}$ See id.

${ }^{17} I d$.

${ }^{18}$ See Lowell H. Lima \& Robert C. Harris, The Child Support Enforcement Program in the United States, in CHILD SUPPORT: FROM DEBT COLLECTION TO SOCIAL POLICY 
limited to those within their jurisdictions, ${ }^{19}$ additional time-consuming procedures are required whenever a child support order is sought to be enforced against a nonresident of the issuing state. ${ }^{20}$ There are also great disparities in the rates of collection and in the success of locating missing obligors among different states; in cases where the custodial parent was receiving Aid to Families with Dependent Children ("AFDC"), ${ }^{21}$ the ten most successful states collected support from only twenty-five percent of nonresident parents, while the least successful states collected support from only $4.1 \%$ of nonresident parents. ${ }^{22}$ Moreover, when custodial parents seek to enforce child support orders in other states, as when they seek to enforce child custody orders, there is a tendency for states with different substantive child support or custody laws to act parochially and modify the orders in accordance with their own laws, thus weakening the finality and certainty of support orders. ${ }^{23}$

As the number of children who live in nontraditional households $^{24}$ increases, ${ }^{25}$ so does the number of children who live in

20, 34 (Alfred J. Kahn \& Sheila B. Kamerman eds., 1988).

${ }^{19}$ See Robert M. Cover Et Al., Procedure 1436-37 (1988) (discussing Pennoyer v. Neff, 95 U.S. 714, 720 (1877) (explaining that the "authority of every tribunal is necessarily restricted by the territorial limits of the State in which it is established $\left.{ }^{n}\right)$ ).

${ }^{20}$ See UNIF. INTERSTATE FAMILY SUPPORT ACT, 9 U.L.A. pt. I, at 231 (1992) (noting that the Uniform Interstate Family Support Act contains a uniform long-arm jurisdictional provision that will allow states to assert jurisdiction over as many nonresident defendants as is constitutionally possible).

21 The AFDC program was begun in 1935 to provide money to dependent children in order to "help maintain and strengthen family life and to help [their] . . parents or relatives to attain or retain capability for the maximum self-support and personal independence consistent with the maintenance of continuing parental care and protection." 42 U.S.C. $\$ 601$ (1994).

${ }^{22}$ See Lima \& Harris, supra note 18, at 41 (citing statistics provided by the Federal Office of Child Support Enforcement). Specific statistics were not provided for nonAFDC families. See id.

${ }^{23}$ See, e.g., Thompson v. Thompson, 484 U.S. 174, 178 (1988) (discussing competing Louisiana and California custody orders); California v. Superior Court, 482 U.S. 400, 402-03 (1987) (discussing a custody debate involving competing orders of California, Texas, and Louisiana). In these situations, states avoid the requirements of the Full Faith and Credit Clause, see U.S. CoNST. art. IV, § 1, by finding procedural or substantive errors in the original orders that make them unenforceable. See Thompson, 484 U.S. at 180 (explaining that states feel entitled to modify custody awards that do not conform to their idea of the child's best interests).

${ }^{24}$ Nontraditional households are those not comprised of a married mother and father. See Constance Sorrentino, The Changing Family in International Perspective, MONTHLY LAB. REV., Mar. 1990, at 41, 41 (defining a traditional nuclear family as composed of "husband, wife, and children living in one household").

${ }^{25}$ See id. at 49-50 \& tbl. 8 (noting that in 1988, more than $20 \%$ of households with dependent children were headed by a single parent and that at least $85 \%$ of 
poverty. ${ }^{26}$ In America today, a significant percentage of the poor are children, ${ }^{27}$ especially children who live in single-mother-headed households. ${ }^{28}$ What is most disturbing about these statistics is that many of these children have been awarded child support by courts as a result of paternity or divorce proceedings. ${ }^{29}$ Because of the unwillingness of many noncustodial parents to pay support obligations, particularly when they are denied visitation rights, ${ }^{30}$ and because of the difficulties involved in collecting child support judgments when the noncustodial parents and the children live in different states, many of these judgments remain uncollected. ${ }^{31}$

single-parent households were run by women, whereas in 1960 , fewer than $10 \%$ of children lived in single-parent households).

${ }^{26}$ See Judith A. Chafel, Child Poverty: Overview and Outlook, in CHILD POVERTY \& PUBLIC POLICY 1, 2 (Judith A. Chafel ed., 1993) (explaining that the child poverty rate increased from 1971 to 1991 and is expected to continue to remain high throughout the 1990s unless remedial measures are enacted).

${ }^{27}$ See National Comm'N ON CHILdRen, BEyond Rhetoric: A New AMERICAN AGENDA FOR CHILDREN AND FAMILIES 24 (1991). The authors of the study noted:

[C]hildren are the poorest Americans. One in five lives in a family with an income below the poverty level .... Nearly 13 million children live in poverty, more than 2 million more than a decade ago. Many of these children are desperately poor; nearly 5 million live in families with incomes less than half the federal poverty level.

Id. (citations omitted); see also William H. Scarbrough, Who Are the Poor? A Demographic Perspective, in CHILD POVERTY \& PUBLIC POLICY, supra note 26, at 55, 5658, 64-78 (defining poverty and describing its differential impact on societal groups defined by age, race, ethnicity, family structure, family size, and geographic location).

${ }^{28}$ See Alfred J. Kahn \& Sheila B. Kamerman, Child Support in the United States: The Problem, in CHILD SUPPORT, supra note 18, at 10, 10 (noting that "[i]n 1985, the poverty rate for children in female-headed families was $54 \%$, in contrast to a $12 \%$ rate for children in all other families").

${ }^{29}$ See Lima \& Harris, supra note 18, at 42 (citing statistics provided by the Office of Child Support Enforcement showing that in 1985, approximately 34,000 families were removed from the AFDC rolls when child support obligations were collected).

${ }^{30}$ See Lizette Alvarez, When Dad Wants to Be More Than Just a Check: Child-Support System Hurts Many Fathers Who Say They Pay Faithfully and Get Little, N.Y. TIMEs, Sept. 8,1995 , at B1 (reporting that the percentage of child support payments made is correlated with the noncustodial parent's visitation rights). But see Lenore J. Weitzman, Child Support Myths and Reality, in CHIL. Support, supra note 18, at 251, 260-61 (citing study results that show no correlation between visitation rights and payment of child support obligations and noting that "most states explicitly forbid the withholding of child support in retribution for the denial of visitation").

${ }^{31}$ See Janelle T. Calhoun, Comment, Interstate Child Support Enforcement System: Juggernaut of Bureaucracy, 46 MERCER L. REV. 921, 921-22 (1995) (discussing the scope of the enforcement problem and noting that "the default rate is nearly $50 \%$ "). But see Lizette Alvarez, Dedicated Dads Defy the "Deadbeat" Image, ATlanTA Const., Oct. 1, 1995, at B4 (explaining the "other side of the story[,] ... that 75 percent of the nation's 5.3 million parents who were supposed to pay child support in 1991 paid either all or some of the amount, according to a 1995 Census Bureau report"). 
Child support awards are made by state courts, which have jurisdiction over family law issues. ${ }^{32}$ Although there have been several attempts in the past century to enact uniform state laws, which would solve the problems that arise in attempting to enforce one state's judgment in another state's courts, none of these laws has been very successful. ${ }^{33}$ Beginning in the $1970 \mathrm{~s}$, the federal government began to take a more active role in the collection of child support debt. That action was a response to the myriad difficulties experienced by custodial parents as a result of the differences among state laws and from the low priority attached by law enforcement officials to interstate support obligations. ${ }^{34}$ In 1975, Title IV-D was added to the Social Security Act, ${ }^{35}$ which required states, as a condition of receiving federal AFDC funding, to provide free child support enforcement services to both AFDC recipients and other custodial parents. ${ }^{36}$

Several other federal laws since that time have provided additional collection mechanisms for parents. ${ }^{37}$ One of the more recent federal acts is the Child Support Recovery Act of 1992 (the "CSRA")," which provides criminal penalties for failure to pay overdue support obligations, ${ }^{39}$ provisions allowing the federal courts to make probation in federal criminal cases dependent on compliance with child support obligations, ${ }^{40}$ and provisions for a program of state grants to aid in developing and enforcing criminal laws to punish those who refuse to pay child support when the parents and the children live in different states. ${ }^{41}$

The passage of the CSRA was mokivated by the federal government's interest in reducing the amount of money it spent on federal benefits, such as AFDC, when the children could receive money from other sources. ${ }^{42}$ The House Committee on the Judiciary,

32 See Lima \& Harris, supra note 18, at 30 (explaining that states are required to specify how child support obligations will be established, either by a state court or administrative agency).

${ }^{33}$ See infra part II.A (discussing the content and goals of these uniform laws).

${ }^{34}$ See S. REP. No. 1356, 93d Cong., 2d Sess. $42-45$ (1974), reprinted in 1974 U.S.C.C.A.N. 8133, 8145-49.

3542 U.S.C. $\$ \S 301-1397$ (1994).

${ }^{36}$ See 42 U.S.C. $\$ 651$ (1994).

${ }^{37}$ See infra part II.C.

${ }^{38}$ Pub. L. No. 102-521, § 2(a), 106 Stat. 3403, 3403 (codified as amended in scattered sections of 18 U.S.C. and 42 U.S.C.).

${ }^{39}$ This provision is now codified at 18 U.S.C. $\$ 228$ (1994).

${ }^{40}$ This provision is now codified at 18 U.S.C. $\$ 3563(\mathrm{~b})(21)$ (1994).

${ }^{11}$ This provision is now codified at 42 U.S.C. $\$ 12301$ (Supp. V 1993).

42 See H.R. REP. NO. 771, 102d Cong., 2d Sess. 5 (1992); see also supra note 21 
which recommended passing the bill, noted that "in 1988, 6.4 million children from homes in which the father was absent were enrolled in ... [AFDG], and that number has steadily increased since that time. ${ }^{43}$ Although the House Report does not specifically address what percentage of those children receiving AFDC are also the beneficiaries of enforceable child support judgments, it assumes that improved collection methods for child support will reduce the number of children who will be eligible to receive AFDC benefits. ${ }^{44}$ Statistics released by the General Accounting Office support this conclusion because only one-fifth of families who received welfare benefits also received child support in $1992 .^{45}$ Health and Human Services Department ( that more effective child support collection devices could easily reduce the total expenditure on AFDC entitlements by up to twentyfive percent on an annual budget of approximately 22 billion dollars. ${ }^{46}$

Recently, congressional involvement in the interstate child support arena has come under constitutional attack from fathers who challenge the legality of the criminal provisions of the CSRA. ${ }^{47}$ This Comment analyzes the constitutionality of the CSRA's criminal provisions and explores the consequences of that analysis. If the challenged provisions are found to be unconstitutional, the federal government will be required to cease its involvement in the criminal aspects of child support enforcement, leaving the states to their own devices. Part I discusses the Commerce Clause theory articulated by United States $v$. Lopez ${ }^{48}$ and the federal district courts' dissention over the application of this theory to the criminal provisions of the CSRA. Part II provides a picture of the states' performances in child support collection in the past and describes the beneficial effects produced by other federal laws in the area of child support enforcement. Part III addresses the various constitutional issues raised by federal involvement in the collection of child

(stating the purposes of AFDC).

${ }^{43}$ H.R. REP. No. 771, 102d Cong., 2d Sess. 5 (1992).

${ }^{44}$ See id.

${ }^{45}$ See Eric Pianin, GAO Calls HHS's Child Support Enforcement Office Ineffective, WASH. POST, July 21, 1994, at A29; see also Diana M. Schobel, Recent Developments: The Maryland General Assembly, 54 MD. L. REV. 891, 905 (1995) (reporting that 90\% of those eligible to receive AFDC benefits "became eligible because of nonpayment of child support").

${ }^{46}$ See Pianin, supra note 45, at A29.

${ }^{47}$ See cases discussed infra part I.B.

48 115 S. Ct. 1624 (1995). 
support debt and the special problems raised by the invocation of federal criminal penalties to deter and punish child support debtors. This Comment concludes that the criminal provisions of the CSRA should be found to be constitutional, both as a matter of law and as a matter of social policy.

\section{The Constitutional Challenge}

In United States $v$. Schroeder, ${ }^{49}$ the federal district court in Arizona held that a criminal provision of the CSRA was unconstitutional because Congress did not have the authority under the Commerce Clause to implement it. ${ }^{50}$ The same court expanded its reasoning in United States $v$. Mussari, ${ }^{51}$ which also found the provision to be unconstitutional. ${ }^{52}$ Attorneys for Jeffrey Nichols hope to invoke these rulings in their favor because FBI agents arrested Nichols under the same provision. ${ }^{53}$ The political response to the Arizona decisions from President Clinton, who disagreed with the rulings, was quick. Clinton released a statement emphasizing that federal action is necessary because "[t]he states cannot bring these criminals to justice-especially the 'hard core' group of parents who flagrantly move from state to state to evade their obligations." ${ }^{n 4} \mathrm{He}$ added that "[p]arental responsibility does not end at the state line. The taxpayers of America should be able to expect that the burden of caring for these children will be placed on the shoulders of the parents-where it rightfully belongs." 55 As will be discussed below, several other cases, which received less publicity, have come to the same conclusion as the federal district court in Arizona.

19894 F. Supp. 360 (D. Ariz. 1995).

${ }^{50} \mathrm{See}$ id. at $362-67$.

51894 F. Supp. 1360 (D. Ariz. 1995).

52 See id. at 1368 . In fact, the discussion sections of the Schroeder and Mussari opinions are often identical.

${ }^{53}$ See Frank J. Murray, Judge Finds Law Unconstitutional, WASH. TIMES, Aug. 28, 1995, at A4 (discussing the Mussari decision); see also supra notes 1-14 and accompanying text (discussing Nichols's notoriety).

${ }^{54}$ Justice Ready to Save "Deadbeat Parent" Law, Charleston GazetTe (S.C.), Aug. 29,1995 , at B6.

${ }^{55} \mathrm{Id}$. 


\section{A. The Impact of United States v. Lopez}

In its holdings, the federal district court in Arizona followed the logic of a recent Supreme Court case, United States v. Lopez, ${ }^{56}$ which held that one criminal provision of the Gun-Free School Zones Act of $1990^{57}$ was unconstitutional because it exceeded Congress's authority under the Commerce Clause. ${ }^{58}$ The Constitution gives Congress the authority " $[t]$ o regulate Commerce with foreign Nations, and among the several States, and with the Indian Tribes. ${ }^{59}$ Decided near the end of the Supreme Court's term in April, 1995, Lopez generated a great deal of controversy and litigation during the following summer. ${ }^{60}$ Marking the first time since $1937^{61}$ that the Court struck down a federal law regulating private activity because it exceeded congressional Commerce Clause powers, ${ }^{62}$ Lopez threw into question the presumption that "commerce clause doctrine grants Congress such broad power that judicial review of the affirmative authorization for congressional action is largely a formality. ${ }^{n 3}$

In Lopez, the Court articulated a three-part test for when Congress may regulate activities under the Commerce Clause:

Congress may regulate [1] the use of the channels of interstate commerce ... [2] the instrumentalities of interstate commerce, or persons or things in interstate commerce, even though the threat may come only from intrastate activities ... [and, 3] those activities having a substantial relation to interstate commerce . . [,] i.e., those activities that substantially affect interstate commerce. ${ }^{64}$

\footnotetext{
${ }^{56} 115$ S. Ct. 1624 (1995).

${ }^{57}$ Pub. L. No. 101-647, $\$ 1702(b)(1), 104$ Stat. 4844, 4844 (codified as amended at 18 U.S.C. $\$ 922(q)(1994))$.

${ }^{58}$ See Lopez, 115 S. Ct. at 1630-31.

${ }^{59}$ U.S. CoNST. art. I, $\S 8$, cl. 3.

${ }^{60}$ See United States v. Bell, 70 F.3d 495, 497 (7th Cir. 1995) (explaining that "United States v. Lopez has raised many false hopes. Defendants have used it as a basis for challenges to various statutes," and listing 10 court of appeals cases decided under Lopez).

${ }^{61}$ In 1937, the Court rejected a rigidly formalistic view of Congress's Commerce Clause authority and ushered in an era of increased tolerance for regulations under the Commerce Clause. See NLRB v. Jones \& Laughlin Steel Corp., 301 U.S. 1, 49 (1937) (holding that Congress could regulate labor relations of employers engaged in interstate commerce).

62 See LAWRENCE H. TRIBE, AMERICAN CONSTITUTIONAL LAW § 5-4, at 309 (2d ed.

${ }^{63}$ Id. $\S 5-8$, at 316 .

${ }^{64}$ United States v. Lopez, 115 S. Ct. 1624, $1629-30$ (1995) (citations omitted).
} 1988). 
Although this language does not appear to be very different from that of the New Deal era cases ${ }^{65}$ that formed the basis for the permissive Commerce Clause doctrine under which Congress operated for most of this century, ${ }^{66}$ the Lopez Court used the language to achieve a much more restrictive goal. ${ }^{67}$ Since the New Deal, Congress has had virtually unlimited power to regulate under the Commerce Clause; the constitutionality of a large number of federal statutes may be in danger if this doctrine changes significantly. ${ }^{68}$

${ }^{65}$ See Wickard v. Filburn, 317 U.S. 111, 125 (1942) (holding that intrastate activity may be regulated "if it exerts a substantial economic effect on interstate commerce"); United States v. Darby, 312 U.S. 100, 118 (1941) (holding that Congress may regulate intrastate activities "which so affect interstate commerce . . . as to make regulation of them appropriate means to the attainment of a legitimate end"); Jones $\mathcal{E}^{2}$ Laughlin, 301 U.S. at 37 (holding that "[a]lthough activities may be intrastate in character when separately considered, if they have such a close and substantial relation to interstate commerce that their control is essential or appropriate to protect that commerce from burdens and obstructions, Congress cannot be denied the power to exercise that control").

${ }^{66}$ See TRIBE, supra note $62, \S 5-8$, at 316 (describing the extent of judicial review of legislation enacted under the Commerce Clause).

${ }^{67}$ See Lopez, 115 S. Ct. at 1634.

${ }^{68}$ See David O. Stewart, Back to the Commerce Clause: The Supreme Court Has Yet to Reveal the True Significance of Lopez, A.B.A. J., July 1995, at 46, 48 (questioning the effect of Lopez on other federal criminal statutes that only arguably deal with "commercial activity," such as the federal crimes of arson of commercial buildings, carjacking, and possession of drugs).

It is unlikely that the Court will revisit Lopez in the foreseeable future; moreover, the Court does not seem likely to change its interpretation of the Interstate Commerce Clause. Since Lopez, the Court has granted certiorari to only three cases raising Commerce Clause issues, and two of these cases only tangentially concern the Commerce Clause. First, in Fulton Corp. v. Justus, 450 S.E.2d 728 (N.C. 1994), cert. granted sub nom. Fulton Corp. v. Faulkner, 115 S. Ct. 1689 (1995), the major issue is whether North Carolina's corporate income tax and intangible personal property tax can be viewed as compensatory taxes such that, when considered together, they do not discriminate against out-of-state corporations. See id. at 729. The resolution of this question is central to whether North Carolina laws violate the dormant Commerce Clause. See id. Second, Barnett Bank v. Gallagher, 43 F.3d 631 (11th Cir. 1995), cert. granted, 116 S. Ct. 39 (1995), involves the interpretation of federal and state provisions to determine whether the statutes in question are truly regulations of "the business of insurance." Id. at 636. Answering this question will probably entail an examination of the congressional understanding of Commerce Clause authority in 1916, the year the statute was passed. See id.

Finally, the most potentially significant impact on Commerce Clause doctrine comes from the Court's recent decision in Seminole Tribe v. Florida, No. 94-12, 1996 WL 134309 (U.S. Mar. 27, 1996). The Court held that Congress does not have the authority to abrogate a state's 11 th Amendment immunity from suit, see U.S. CONST. amend XI, when the state acts under the authority of the Indian Commerce Clause, see U.S. CoNST. art. I, § 8, cl. 3. See Seminole Tribe, 1996 WL 134309, at *3. The Court had previously allowed Congress to abrogate states' 11th Amendment 
The federal district court in Arizona decided that federal involvement in child support enforcement is constitutionally inappropriate. The portion of the CSRA that was overturned in Schroeder and Mussari makes it a federal crime to "willfully fail[] to pay a past due support obligation with respect to a child who resides in another State," and provides both fines and terms of imprisonment for those convicted under the statute. ${ }^{69}$ The district court found that the constitutionality of this provision should be judged by the third criterion established in Lopez: whether the failure to pay child support obligations "substantially affect[s] interstate com-

immunity when acting pursuant to the Interstate Commerce Clause. See Pennsylvania v. Union Gas Co., 491 U.S. 1, 19 (1989) (plurality opinion). Applying the logic of that case, the Court found that there was "no principled distinction in favor of the States to be drawn between the Indian Commerce Clause and the Interstate Commerce Clause." Seminole Tribe, 1996 WL 134309, at *10. By overruling Union Gas, the Court clarified its belief that Congress may not abrogate a state's immunity from suit when it legislates under the Interstate Commerce Clause. See id. at *13. This ruling could provide strong precedent for a line of cases that would limit Congress's authority to act under the Interstate Commerce Clause when such regulation threatens principles of federalism, as it does in this case. While it is highly unlikely that the decision in Seminole Tribe will directly affect any of the litigation under Lopez, this decision may well be indicative of the direction of the Court's leaning with regard to the appropriate balances of state and federal power.

${ }^{69} 18$ U.S.C. $\$ 228$ (1994). The complete section reads as follows:

Failure to pay legal child support obligations.

(a) Offense.-Whoever willfully fails to pay a past due support obligation with respect to a child who resides in another State shall be punished as provided in subsection (b).

(b) Punishment.-The punishment for an offense under this section is-

(1) in the case of a first offense under this section, a fine under this

title, imprisonment for not more than 6 months, or both; and

(2) in any other case, a fine under this title, imprisonment for not more than 2 years, or both.

(c) Restitution.-Upon a conviction under this section, the court shall order restitution under section 3663 in an amount equal to the past due support obligation as it exists at the time of sentencing.

(d) Definitions.-As used in this section-

(1) the term "past due support obligation" means any amount-

(A) determined under a court order or an order of an administrative process pursuant to the law of a State to be due from a person for the support and maintenance of a child or of a child and the parent with whom the child is living; and

(B) that has remained unpaid for a period longer than one year, or is greater than $\$ 5,000$; and

(2) the term "State" includes the District of Columbia, and any other possession or territory of the United States.

Id. 
merce. ${ }^{\text {"0 }}$ In some of the other federal district courts' cases, the theories advanced in support of the provision failed to demonstrate a sufficient connection between interstate commerce and the punishment of delinquent child support obligors for the courts to justify federal intervention. ${ }^{71}$ The Schroeder court found that "the fact that this statute is a criminal statute aimed at an area of activity which has already been addressed by the States supports this court's finding that the [provision] is not substantially related to interstate commerce. ${ }^{\text {72 }}$

\section{B. The District Court Split}

Several other federal district courts have ruled on the constitutionality of the criminal provision at issue in Schroeder and Mussari. ${ }^{73}$ In United States $v$. Bailey, ${ }^{74}$ a federal district court in Texas agreed with the Schroeder and Mussari courts in finding $§ 228$ of the CSRA (" $\$ 228$ ") ${ }^{75}$ unconstitutional. ${ }^{76}$ A federal district court in Pennsylvania, in United States $v$. Parker, ${ }^{77}$ also reached the same conclusion, although its rationale was slightly different. ${ }^{78}$ Five cases have gone the other way, however, upholding the statute's constitutionality. ${ }^{79}$ These cases argue that the failure to pay child

${ }^{70}$ Lopez, 115 S. Ct. at 1630; see also United States v. Mussari, 894 F. Supp. 1360, 1363 (D. Ariz. 1995) (asserting that "if [\$ 228 of] the CSRA is to be upheld, it would have to be as a regulation of activities having a 'substantial relation to interstate commerce'" (quoting Lopez, 115 S. Ct. at 1629-30)); United States v. Schroeder, 894 F. Supp. 360, 364 (D. Ariz. 1995) (same).

${ }^{7}$ See infra notes 245-54 and accompanying text.

72 Schroeder, 894 F. Supp. at 364.

73 As of the date of this Comment, no court of appeals has ruled on the constitutionality of $\S 228$. The following cases are currently before the circuit courts: United States v. Parker, 911 F. Supp. 830 (E.D. Pa. 1995), appeal docketed, No. 95-2018 (3d Cir. Nov. 30, 1995); Únited States v. Sage, 906 F. Supp. 84 (D. Conn. 1995), appeal docketed, No. 96-1007 (2d Cir. Jan. 2, 1996); United. States v. Bailey, 902 F. Supp. 727 (W.D. Tex. 1995), appeal docketed, No. 95-50721 (5th Cir. Oct. 4, 1995); United States v. Schroeder, 894 F. Supp. 360 (D. Ariz. 1995), appeal docketed, No. 9510513 (9th Cir. Nov. 1, 1995); and United States v. Hampshire, 892 F. Supp. 1327 (D. Kan. 1995), appeal docketed, No. 96-3007 (10th Cir. Jan. 5, 1996).

7402 F. Supp. 727 (W.D. Tex. 1995).

${ }^{75} 18$ U.S.C. § 228 (1994).

${ }^{76}$ See Bailey, 902 F. Supp. at 730 .

7711 F. Supp. 830 (E.D. Pa. 1995).

${ }^{78}$ See infra notes 236, 248-54 and accompanying text.

${ }^{79}$ See United States v. Kegel, No. 95-300-CR-T-21(E), 1996 WL 69725, at *2 (M.D. Fla. Feb. 13, 1996) (finding that "upon close analysis there is a rational link between commerce and the harm proscribed by this statute"); United States v. Sage, $906 \mathrm{~F}$. Supp. 84, 92 (D. Conn. 1995) (finding that a "rational basis exists for finding that non-payment of past due child support substantially affects interstate commerce"); 
support is an economic activity that has a substantial effect on interstate commerce when all individual instances of nonpayment are aggregated. ${ }^{80}$ The fundamental points of contention between the courts upholding the statute and those striking down the statute seem to be the definition of the concept of "commerce" and the concern that the definition must be carefully constructed to provide meaningful limits to the concept.

In applying the standards set forth in Lopez, the federal district courts disagree in four main areas: (1) whether the statute has a valid jurisdictional element that establishes an interstate link; ${ }^{81}$ (2) whether the activities regulated in the criminal statute qualify as "commerce"; ${ }^{n 2}$ (3) whether the legislative history supports a conclusion that interstate commerce is being regulated; ${ }^{83}$ and (4) whether general principles of federalism and comity support this exercise of congressional authority. ${ }^{84}$ In resolving the Tenth Amendment question, ${ }^{85}$ which is essentially the converse of Commerce Clause analysis, ${ }^{86}$ the courts also raise issues concerning the doctrine requiring federal court abstention in the area of domestic relations and other federal abstention doctrines. ${ }^{87}$ The final resolution of these issues will determine what role the federal

United States v. Hopper, 899 F. Supp. 389, 394 (S.D. Ind. 1995) (finding that the statute "specifically limits itself to circumstances involving interstate commerce" and "the collection of child support payments is a matter that substantially affects interstate commerce"); United States v. Murphy, 893 F. Supp. 614, 616 (W.D. Va. 1995) (finding that the statute has "a jurisdictional element that ensures it will not intrude upon matters with no relation to interstate commerce"); United States v. Hampshire, 892 F. Supp. 1327, 1331 (D. Kan. 1995) (finding that the statute is constitutional "because the requirement of an interstate relationship is one of the explicit elements of the crime").

${ }^{80}$ See, e.g., Hopper, 899 F. Supp. at 393 (finding that the "collection of child support orders across state lines does involve a continuous and indivisible stream of intercourse among the states").

${ }^{81}$ See infra part III.A.1.

${ }^{82}$ See infra part III.A.2.

${ }^{83}$ See infra part III.A.3.

${ }^{84}$ See infra part III.A.4.

${ }^{85}$ See U.S. CONST. amend X.

${ }^{86}$ If Congress has acted within the limits of its Commerce Clause authority, then it has acted constitutionally. If Congress has overstepped the limits of the authority granted in its enumerated powers, however, then Congress has violated the Tenth Amendment by infringing on the powers reserved to the states. See infra part III.A.4.a; see also New York v. United States, 505 U.S. 144, 155-56 (1992) (holding that the Tenth Amendment and Commerce Clause analyses are "mirror images of each other").

${ }^{87}$ See infra part III.A.4.b. 
government may take in creating more effective child support collection and enforcement policies.

\section{The EFFECTtVENESS OF STATE Versus FEDERAL CHILD SUPPORT ENFORCEMENT}

The necessary consequence of finding $\$ 228$ unconstitutional under the Commerce Clause is that child support enforcement will be left solely to state civil enforcement provisions and state criminal law. ${ }^{88}$ The Schroeder court argues that this is a desirable result because the current civil and criminal enforcement scheme is effective. ${ }^{89}$ Likewise, the Bailey court feels that state action has been more than adequate in enforcing child support judgments. To support its conclusion that "numerous remedies" exist to enforce the rights of custodial parents, the court lists fifteen pieces of Texas legislation that directly concern child support enforcement..$^{90}$ On the other hand, the court in Parker admits that child support enforcement in the United States is a problem and that federal criminal laws may be the only available means to solve this problem, but nonetheless it maintains that $\S 228$ is an unconstitutional use of congressional power to achieve worthy objectives. ${ }^{91}$

Contrary to the argument in Bailey, the multiplicity of state statutes concerning remedies for custodial parents in child support cases does not necessarily mean that those statutes are effective, particularly in interstate enforcement actions. In 1992, only one of every ten dollars ordered to be paid in interstate child support cases was actually collected..$^{92}$ One of the reasons that states are ineffective collectors in interstate cases is that the reach of state

88 The federal government, however, is not completely powerless. The federal government, using its spending power, may require that states adopt particular regulations as a necessary condition of receiving federal funding for child support enforcement agencies but would be unable to regulate individual behavior directly. See U.S. CoNST. art. I, § 8, cl. 1 ("The Congress shall have Power To lay and collect Taxes . . . to pay the Debts and provide for the common Defence and general Welfare of the United States .....").

${ }^{89}$ See United States v. Schroeder, 894 F. Supp. 360, 364 (D. Ariz. 1995).

${ }^{90}$ See United States v. Bailey, 902 F. Supp. 727, 729-30 (W.D. Tex. 1995).

${ }^{91}$ See United States v. Parker, 911 F. Supp. 830, 843 (E.D. Pa. 1995) ("In its effort to solve the problem being experienced by many states in collecting unpaid child support, Congress, though well-intentioned, exceeded its authority and invaded the realm of sovereignty carefully reserved to the states.").

${ }^{92}$ See JUdITH AREEN, CASES AND MATERIALS ON FAMILY LAW 112 (3d ed. Supp. 1995) (citing a 1992 report to Congress, entitled Supporting Our Children, A Blueprint for Reform, that was written by the U.S. Commission on Interstate Child Support). 
statutes is limited to those people within their jurisdiction. ${ }^{93}$ Thus, state law has an inherent disadvantage when it is compared to federal law in extraterritorial interstate proceedings. The reasons why federal involvement in interstate cases is an important, and perhaps crucial, factor in the effort to improve child support enforcement beyond its current level of marginal effectiveness is discussed below.

\section{A. Past Attempts By States to Improve Interstate Enforcement}

In the last century, there have been several attempts by the Commissioners on Uniform State Laws (the "Commissioners") to pass uniform laws simplifying the enforcement procedure for out-ofstate judgments. ${ }^{94}$ One of the difficulties with these uniform state acts is that they are often changed by state legislatures; ${ }^{95}$ although the individual changes may be minor, the convenience and simplicity of having a uniform law is destroyed when practitioners must deal with many small variations among states. Another source of confusion arises in cases in which a new or revised uniform act replaces an old one. Although many states repeal the old uniform act when they adopt the new one, some states choose to enact the new uniform act without repealing the old one. ${ }^{96}$ This leads to confusion as to whether procedures from the old act may remain effective in instances in which the new act does not specify otherwise.

${ }^{93}$ See COVER ET AL., supra note 19, at 1434-42 (discussing the territorial jurisdiction prerequisite for state courts).

${ }^{94}$ Two early efforts at creating uniform laws were the Uniform Reciprocal Enforcement of Support Act ("URESA"), see 9B U.L.A. 553 (1958), and the Revised Uniform Reciprocal Enforcement of Support Act ("RURESA"), see 9B U.L.A. 381 (1968). Although every state passed either URESA or RURESA, thereby putting a simplified enforcement procedure in place, interstate judgments remained difficult to collect. See UNif. INTERSTATE Family SUPPORT ACT, Prefatory Note, 9 U.L.A. pt. I, at 230 (1992) (noting that "some version of URESA or RURESA has been adopted in all states"). The most recent attempt to pass a uniform law, the Uniform Interstate Family Support Act ("UIFSA") was designed to correct the flaws of URESA and RURESA. See id. UIFSA has been adopted, albeit in slightly modified form, by 20 states to date. See Table of Jurisdictions, 9 U.L.A. pt. I, at 229.

${ }_{95}$ See infra notes 154-56 and accompanying text.

${ }^{6}$ See UNIF. INTERSTATE FAMILY SUPPORT ACT, General Statutory Note, 9 U.L.A. pt. I, at 233 (1992) (noting that of the 20 states that have enacted UIFSA to date, three of those states, Arizona, Illinois, and Oregon, enacted UIFSA without repealing RURESA). 


\section{UDNA}

In 1910, the Commissioners proposed the Uniform Desertion and Nonsupport Act ("UDNA"), ${ }^{97}$ which was eventually adopted in twenty-one states. ${ }^{98}$ UDNA's effectiveness was limited because it only provided for criminal penalties for failure to pay either alimony or child support; UDNA did not provide any civil provisions for the collection of debts. ${ }^{99}$ The usefulness of the criminal provision was also limited by the Act's failure to instate direct interstate enforcement procedures. ${ }^{100}$ A prerequisite to bringing criminal charges under the statute, in instances in which the father had fled from his dependents' state of residence, was the return of the father, either voluntarily or through extradition, to the state that issued the original support order. ${ }^{101}$ Not only was it difficult for custodial parents to prove one of the requirements for extradition, that the

9710 U.L.A. 1 (1910) (Act withdrawn 1966).

${ }^{93}$ See COMMISSIONERS ON UNIFORM STATE LAWS, HANDBOOK OF THE NATIONAL Conference of Commissioners on UNiform State LAWS and ProceEdings of THE THIRTY-SIXTH ANNUAL MEETING 34 (1926). UDNA was adopted in full by Alabama, California, Idaho, Kansas, North Dakota, Massachusetts, Mississippi, Nevada, Texas, Utah, Vermont, Washington, West Virginia, Wisconsin, and Wyoming. Six states, Alaska, Delaware, Hawaii, Illinois, New Jersey, and Virginia, adopted the Act with modifications. See id.

${ }^{99}$ See UNIF. DESERTION AND NONSUPPORT AcT § 1, 10 U.L.A. 1 (1910) (Act withdrawn 1966) (stating that one who fails to provide support to a needy wife or child can "still be guilty of a crime"). The only provision that provided for payment to dependents was UDNA $\$ 7,10$ U.L.A. 77, which required correctional facility officials to release to the inmate's dependents any money that the inmate earned from hard labor.

${ }^{100}$ See UNIF. RECIPROCAL ENFORCEMENT OF SUPPORT ACT, Prefatory Note (1950 version), 9B U.L.A. 556 (1958) (asserting that a defect of the 1910 Act was that "it made no reference to enforcement as against husbands and fathers who fled from the state"); see also Tina M. Fielding, Note, The Uniform Interstate Family Support Act: The New URESA, 20 U. DAYTON L. REv. 425, 428 (1994) (explaining that "while UDNA was an important step in enforcing support obligations, it did little to transfer money from the obligor to the obligee and/or her children"). Unhappy with the absence of civil interstate enforcement procedures from UDNA, New York legislators drafted and passed the Uniform Support of Dependents Law ("USDL") in 1949. See 1949 N.Y. Laws 807. This statute was eventually adopted in New York, Georgia, Illinois, and Iowa. See Legislation, New York Uniform Support of Dependents Law-Its Operation to Date, 30 ST. JOHN'S L. REV. 309, 310 n.13 (1956). USDL, interestingly, was a civil provision that required an individual to support not only a spouse and children, but also certain close relatives, such as parents or grandchildren. See id. at 312 n.30. New York never adopted URESA or RURESA, but rather modified its USDL to conform with those evolving uniform acts. See N.Y. DoM. ReL. LAw \$ 30, Practice Commentaries (McKinney 1988).

- ${ }^{101}$ See UNIF. RECIPROCAL ENFORCEMENT OF SUPPORT ACT, Prefatory Note (1950 version), 9B U.L.A. 556 (1958). 
noncustodial parent "fled from justice"102 instead of merely leaving the state for employment reasons, but it was also an expensive endeavor-the legal and court fees involved in bringing such an action made extradition a rarely pursued remedy. ${ }^{103}$ The drafters of URESA also explained other problems with UDNA: "The proceedings rendered reconciliation with the family improbable, took him away from his job in the state to which he had fled, and by branding him a convicted criminal lessened the probabilities of gainful employment in the home state. ${ }^{104}$ Realizing that a more comprehensive solution was needed for the growing problem of interstate support obligations, ${ }^{105}$ the Commissioners began work on a new uniform law in $1946 .{ }^{106}$

\section{URESA and RURESA}

By the early 1980 s, every state had passed some version of URESA, ${ }^{107}$ approved by the Commissioners in 1950, or RURESA, ${ }^{108}$ approved by the Commissioners in $1968 .{ }^{109}$ Both of these laws provide primarily civil remedies that attempt to solve some of the problems associated with the recognition and enforcement by one state of child support judgments from the courts of other states. ${ }^{110}$ Under these Acts, there are two primary methods for the collection of support: (1) two-state proceedings and (2) the registration of foreign orders (registration of an order in a state other than the state that initially granted the order). ${ }^{11}$ Both of

${ }^{102} \mathrm{Id}$.

${ }^{103}$ See id.

${ }^{104} \mathrm{Id}$.

${ }^{105}$ See id. (noting that $\$ 205$ million was being spent annually by 1949 in aid to families in which the father was absent and not providing support to his family).

${ }^{106}$ See COMMISSIONERS ON UNIFORM STATE LAWS, HANDBOOK OF THE NATIONAL CONFERENCE OF COMMISSIONERS ON UNIFORM STATE LAWS AND PROCEEDINGS OF THE FIFTY-FOURTH ANNUAL CONFERENCE 278-79 (1944) (reporting to the Conference that UDNA had been substantially changed by many states, a sign that the Act no longer met the child support enforcement needs of many states, and recommending that UDNA's status be changed to that of a Model Act).

107 9B U.L.A. 553 (1958).

${ }^{108}$ 9B U.L.A. 381 (1968).

${ }^{109}$ See UNIF. INTERSTATE FAMILY SUPPORT ACT, 9 U.L.A. pt. I, at 229 (1992).

110 See, e.g., UNIF. RECIPROCAL ENFORCEMENT OF SUPPORT ACT, Prefatory Note (1958 version), 9B U.L.A. 553 (1958) (stating that URESA's "purpose has been, and is, . . . to provide by reciprocal legislation for the enforcement, across state lines, of duties of support already existing").

111 Two-state proceedings are discussed in REVISED UNIF. RECIPROCAL ENFORCEMENT OF SUPPORT ACT $\$ \$ 7-34,9 B$ U.L.A. $423-540$ (1968), and registration is 
these procedures are designed to reduce the cost and delay of efforts by custodial parents to recover child support money. ${ }^{112}$ The statutes also provide provisions encouraging extradition of those debtors found to have violated criminal support laws, although these Acts do not themselves provide direct criminal penalties for nonpayment. ${ }^{113}$

\section{a. Two-State Proceedings}

One way for a custodial parent to enforce a support obligation is to initiate a two-state proceeding. ${ }^{114}$ The custodial parent begins a suit by filing a petition, in her or her child's home state (called the "initiating state"), describing the circumstances surrounding the past-due support and providing all of the information she has about the noncustodial parent's whereabouts. ${ }^{115}$ The initiating state's court ("the initiating court") must then determine whether the petition "sets forth facts from which it may be determined that the obligor owes a duty of support" and whether the courts of the obligor's state of residence "may obtain jurisdiction of the obligor or his property. ${ }^{116}$ If the initiating court answers these questions affirmatively, then it must certify the petition to the courts of the obligor's state of residence, the "responding state." 117 The responding court then assumes complete jurisdiction over the matter. ${ }^{118}$ The responding court has the obligation to notify the

discussed in REVISED UNIF. RECIPROCAL ENFORCEMENT OF SUPPORT ACT $§ \$ 35-40,9 B$ U.L.A. 540-50 (1968).

${ }^{112}$ See REVISED UNIF. RECIPROCAL ENFORCEMENT OF SUPPORT ACT, Prefatory Note, 9B U.L.A. 382 (1968).

113 See REvised UNIF. RECIPROCAl ENFORCEMENT OF SUPPoRT AGT § 5, 9B U.L.A. 416 (1968) (enabling state governors to demand the extradition from another state, and to extradite from their own states, a person criminally charged for failure to provide support to any person).

114 See REVISED UNIF. RECIPROCAL ENFORCEMENT OF SUPPORT ACT § 11, 9B U.L.A. 440 (1968) (outlining the necessary procedures regarding filing and venue for initiating a two-state proceeding).

${ }^{115}$ The "initiating state" is defined in REvISED UNIF. RECIPROCAL ENFORCEMENT OF SUPPORT ACT § 2(d), 9B U.L.A. 402 (1968). The necessary contents of the petition are described in REVISED UNIF. RECIPROCAL ENFORCEMENT OF SUPPORT ACT \$ 11,9B U.L.A. 440 (1968).

${ }^{116}$ REVISED UNIF. RECIPROCAL ENFORCEMENT OF SUPPORT ACT \$ 14, 9B U.L.A. 450 (1968); see also William F. Fox, The Uniform Reciprocal Enforcement of Support Act, 12 FAM. L.Q. 113, 120 (1978) (noting that the initiating state makes a judgment akin to a probable cause determination in a criminal case).

117 See REVISED UNIF. RECIPROCAL ENFORCEMENT OF SUPPORT ACT \& 2(l), 9B U.L.A. 403 (1968) (defining "responding state").

${ }^{118}$ See REVISED UNIF. RECIPROCAL ENFORCEMENT OF SUPPORT ACT \$§ 18-19, 9B 
proper state agency, which will obtain jurisdiction over the obligor and serve him with the complaint. ${ }^{119}$ After conducting a civil trial under its own laws, the responding state must determine whether a support obligation exists and, if such an obligation does exist, may then order the payment of the past-due support as well as other reimbursement. ${ }^{120}$

\section{b. Registration of Orders}

Alternatively, a custodial parent, who has already obtained a child support order in her or her child's state of residence, may seek to have that order registered and enforced in the noncustodial parent's state of residence. ${ }^{121}$ The custodial parent must first file the existing order in the responding state. ${ }^{122}$ Then, the responding state must notify the noncustodial parent and provide him with the opportunity to petition to have the order vacated on grounds of lack of personal jurisdiction or to have the order stayed pending appeal in the state where the order was originally issued. ${ }^{123}$ If the noncustodial parent accepts the jurisdiction of the responding court, either through active acceptance or through failure to petition the court in a timely manner, the responding court can enforce the order as if it were originally issued by that court. ${ }^{124}$ If the order can be enforced just like any original order of the responding court, the issue arises whether the responding court can then modify the order just as it may modify any of its other orders; ${ }^{125}$ neither URESA nor RURESA provides a clear answer to this question, and states have reached opposite conclusions

U.L.A. 461, 467 (1968) (describing the duties of the court in the responding state). ${ }^{119}$ See REVISED UNIF. RECIPROCAL ENFORCEMENT OF SUPPORT ACT $\$ 19$, 9B U.L.A. 467 (1968).

${ }^{120}$ See ReVISEd UNIF. Reciprocal ENFORCEMENT OF SUPPORT ACT $\$ 7,9 B$ U.L.A. 423 (1968) (describing which state's law is to be applied). The resulting order of support is described in REVISED UNIF. RECIPROCAL ENFORCEMENT OF SUPPORT ACT $\S 24,9$ B U.L.A. 487 (1968).

${ }^{121}$ See REVISED UNIF. RECIPROCAL ENFORCEMENT OF SUPPORT ACT \$§ 35-36, 9B U.L.A. 540-41 (1968) (describing the procedures for the registration of foreign support orders).

${ }_{122}$ See Revised UNIF. RECIPROCAL ENFORCEMENT OF SUPPORT ACT $§ 39(\mathrm{a}), 9 \mathrm{~B}$ U.L.A. 543 (1968).

${ }^{123}$ See REVISED UNIF. RECIPROCAL ENFORCEMENT OF SUPPORT ACT $\$$ 40, 9B U.L.A. 546 (1968) (describing the effects of registration and enforcement procedures). ${ }^{124}$ See id.

${ }^{125}$ See MARIANNe TAKas, ChILd Support 73 (1985) (noting that child support awards may be modified because of changed circumstances). 
regarding the extent of the responding court's authority to modify orders. ${ }^{126}$

\section{UIFSA}

UIFSA $^{127}$ is the newest, and most promising, uniform state law to enter the battle against overdue support obligations. Since its approval by the Commissioners in 1992, however, UIFSA has been adopted, albeit in slightly modified form, by only twenty states. ${ }^{128}$ UIFSA was designed to respond to new federal legislation that affected child support laws to eliminate the problems of multiple effective support orders that resulted from URESA proceedings in different states and to streamline some of the procedures for registration and modification of support orders. ${ }^{129}$ Of all the changes made by UIFSA, three are likely to create the most significant improvements in interstate support enforcement: ${ }^{130}$ (1) the establishment of a uniform and broad long-arm jurisdiction provision; ${ }^{131}$ (2) the introduction of the principle of continuing exclusive jurisdiction; ${ }^{132}$ and (3) the limitation of the responding court's ability to modify orders that come before it. ${ }^{133}$ While these reforms promise to solve some of the problems that now occur when one state's child support orders are sought to be enforced by the courts of another state, UIFSA does nothing to address the problems resulting from the current ineffective methods of finding and punishing obligors who willfully choose not to pay. These reforms neither strengthen the extradition powers of the

${ }^{126}$ See REVISED UNIF. ReCIPROCAL ENFORCEMENT OF SUPPORT ACT § 31, 9B U.L.A. 531 (1968) (exploring, in ambiguous language, whether the original support order may be modified by a subsequent court's action); REVISED UNIF. RECIPROCAL ENFORCEMENT OF SUPPORT ACT \& 30, 9B U.L.A. 529 (1968) (stating that no order of support issued by a court acting as a responding court shall supersede other orders of support); see also Fielding, supra note 100, at 442-44 (discussing courts' various interpretations of the responding court's authority to modify orders).

${ }^{127} 9$ U.L.A. pt. I, at 229 (1992).

${ }^{128}$ See UNIF. INTERSTATE FAMILY SUPPORT ACT, Table of Jurisdictions, 9 U.L.A.pt. I, at 229 (noting that, as of July 1, 1995, the Act has been adopted in Arizona, Arkansas, Colorado, Delaware, Idaho, Illinois, Kansas, Maine, Minnesota, Montana, Nebraska, New Mexico, Oklahoma, Oregon, South Carolina, South Dakota, Texas, Virginia, Washington, and Wisconsin).

${ }_{129}$ See Prefatory Note, 9 U.L.A. pt. I, at 230.

${ }^{150}$ See id. at 231-33.

${ }^{131}$ See $\$ 201,9$ U.L.A. pt. I, at 242.

${ }^{132}$ See $\S \S 204-206,9$ U.L.A. pt. I, at 246-48.

${ }^{199}$ See $\$ \S 609-612,9$ U.L.A. pt. I, at $278-82$ (detailing the procedures for registration and modification of support orders). 
states nor adopt uniform civil or criminal sanctions, thus ignoring the importance of providing the states with the power to coerce obligors to pay their obligations.

\section{a. Long-Arm Jurisdiction}

UIFSA provides, for the first time, a uniform long-arm jurisdictional statute in "proceeding[s] to establish, enforce, or modify a support order or to determine parentage," which is as broad as the Constitution permits. ${ }^{134}$ The comment to this section recognizes that many states do not have specific domestic relations long-arm statutes and also that some state statutes do not allow the exercise of jurisdiction to the maximum extent possible under the Constitution. ${ }^{135}$ UIFSA will not only reduce confusion for interstate litigants as to the relevant long-arm statute, but also will enable an obligee to avoid a two-state proceeding altogether by simply asserting jurisdiction over the out-of-state obligor in the obligee's home state.

\section{b. Continuing Exclusive Jurisdiction.}

UIFSA also adopts the principle of continuing exclusive jurisdiction from the Uniform Child Custody Jurisdiction Act ("UCCJA"). ${ }^{136}$ By providing that an order may be modified only by the court that originally issued it, this principle makes valid only one support order for each parent-child relationship at any given time. ${ }^{137}$ Thus, a responding court will be discouraged from creating a new support order with different terms because the responding court's order will be ineffective as long as the initiating court retains its exclusive jurisdiction. UIFSA's drafters recognize

${ }^{134} \S 201,9$ U.L.A. pt. I, at 242; see also Burnham v. Superior Court, 495 U.S. 604, 628 (1990) (holding that personal service of process within a state is sufficient to support that state's exercise of jurisdiction); Kulko v. Superior Court, 436 U.S. 84, 101 (1978) (holding that the presence of a noncustodial parent's child within the state does not support the court's exercise of personal jurisdiction over the nonresident, noncustodial parent).

${ }^{135}$ See UNIF. INTERSTATE FAMILY SUPPORT ACT $\$ 201 \mathrm{cmt}$, 9 U.L.A. pt. I, at 242.

1369 U.L.A. pt. I, at 115 (1968); see also infra notes 150-52 and accompanying text (discussing the application of the continuing exclusive jurisdiction principle to strengthen the enforceability of child support orders under the Full Faith and Credit Clause). This provision is found at $\$ 205$ of UIFSA. See UNIF. INTERSTATE FAMILY SUPPORT ACT $\$ 205,9$ U.L.A. pt. I, at 246 (1992).

${ }^{137}$ See UNIF. INTERSTATE FAMILY SUPPORT AGT $§ \S ~ 204-206,9$ U.L.A. pt. I, at 245-48 (1992). 
that there are many multiple orders in the United States today, and although UIFSA does not include provisions designed to eliminate any of the existing multiple orders, the drafters hope that strict observance of the continuing exclusive jurisdiction rule will prevent the promulgation of future multiple orders. ${ }^{138}$

\section{c. Limitations on Modification}

Another consequence of the continuing exclusive jurisdiction principle is that, except in some narrow factual situations, only one state will be able to modify existing orders at any given time. ${ }^{139}$ Once a state obtains continuing exclusive jurisdiction over an order, another state can only modify that order (1) if none of the parties (including the child, the individual obligee, and the obligor) remain in the first state or (2) if all the parties file written consents in the first state to transfer continuing exclusive jurisdiction to the other state. ${ }^{140}$ The rather common practice of support order modification under URESA and RURESA will be eliminated under UIFSA, and UIFSA's drafters hope that the doctrine of continuing exclusive jurisdiction will keep both custodial and noncustodial parents from forum shopping for a state whose substantive child support law favors their claim. ${ }^{141}$

\section{B. The Problems with State Enforcement Efforts}

\section{Legal Problems}

\section{a. The Full Faith and Credit Clause}

The basic problem facing custodial parents who try to enforce child support orders against noncustodial parents who live in different states is that a state court only has authority over those people within its jurisdiction, which is defined by the

${ }^{198}$ See $\$ 204 \mathrm{cmt} ., 9$ U.L.A. pt. I, at 245 (noting the importance of creating a procedure to "eliminate the multiple orders so common under RURESA and URESA $^{n}$ ); Fielding, supra note 100, at 459 (asserting that the policy of continuing exclusive jurisdiction "furthers the goal of single orders").

139 See UNIF. INTERSTATE FAMILY SUPPORT ACT §§ 609-612, 9 U.L.A. pt. I; at 278-82 (1992).

${ }^{140}$ See $\$ 611($ a), 9 U.L.A. pt. I, at 279.

${ }^{141} \mathrm{See} \$ 611 \mathrm{cmt} ., 9$ U.L.A. pt. I, at 280 (stating that UIFSA is aimed at eliminating the problems that occur when "[t]ribunals in other states ... assume jurisdiction to enter new orders or to modify an out-of-state support order"). 
state's long-arm jurisdiction statute. ${ }^{142}$ For example, when an order for child support is entered against a noncustodial parent in the courts of state $A$, and the noncustodial parent is a citizen of state $B$, the courts of state $A$ will have no direct means of enforcing their order if the long-arm statute does not provide for jurisdiction over the noncustodial parent. As a result, the custodial parent must seek to register the order of state $A$ in the courts of state $B .{ }^{143}$ This process might appear to be relatively simple, since the Full Faith and Gredit Clause of the United States Constitution provides that "Full Faith and Credit shall be given in each State to the public Acts, Records, and Judicial Proceedings of every other State." ${ }^{144}$ In fact, the process is quite difficult, for the Full Faith and Credit Clause only applies to final and unmodifiable judgments. ${ }^{145}$ By their nature, child support orders are forward-looking toward the possibility of changed circumstances and are, thus, inherently modifiable. ${ }^{146}$ Therefore, the Full Faith and Credit Clause does not necessarily apply to child support judgments.

In order to emphasize the importance of the Full Faith and Credit Clause in situations involving the enforcement of overdue child support obligations, Congress passed the Full Faith and Credit for Child Support Orders Act in 1994. ${ }^{147}$ This Act was an attempt to make child support orders more enforceable once the support payments became overdue, by making the orders less modifiable. ${ }^{148}$ Congress specifically found that the jurisdictional limits of state law "lead to the excessive relitigation of cases and to the establishment of conflicting orders by the courts of vari-

${ }^{142}$ See David CRump et al., Cases and Materials on Civil Procedure $\S 2.02(B)(3)$, at 82 (2d ed. 1992) (discussing the various ways that states define their extraterritorial jurisdiction).

${ }^{143}$ See supra part II.A.2.b (discussing the registration of orders).

${ }^{144}$ U.S. CONST. art. IV, $\S 1$.

${ }^{145}$ See Sistare v. Sistare, 218 U.S. 1, 17 (1910) (holding that the Full Faith and Credit Clause protects the right to periodic alimony payments once this right "becomes absolute and vested," a condition that requires that "the right to demand and receive" such payments must not be "discretionary with the court which rendered the decree").

${ }^{146}$ See, e.g., Graham v. Graham, 597 A.2d 355, 357-58 (D.C. 1991) (holding that changes in a parent's lifestyle and income justify the modification of child support orders).

${ }^{147}$ The Act, now codified at 28 U.S.C. $\$ 1738 \mathrm{~B}$ (1994), became law on October 20, 1994. See Pub. L. No. 103-383, § 3(a), 108 Stat. 4063, 4064-66 (1994).

${ }^{148}$ See Pub. L. No. 103-383, § 2, 108 Stat. 4063, 4063-64 (1994) (explaining the purposes of the Act). 
ous jurisdictions, resulting in confusion, waste of judicial resources, disrespect for the courts, and a diminution of public confidence in the rule of law."149 The Act's goal was achieved through adoption of the continuing exclusive jurisdiction approach of UCCJA, which states that only one state, the child's "home state," may act to modify a child custody award. ${ }^{150}$ As a result, child support judgments are more likely to be enforced under the Full Faith and Credit Clause because they are unmodifiable except by the court that has continuing exclusive jurisdiction over them. ${ }^{151}$ This Federal Act, however, cannot solve the problem that is created by some state laws that do not declare child support orders to be final when they become due, but rather declare them to be final when, and if, the court later enters judgment on a past-due amount. ${ }^{152}$

${ }^{149}$ Full Faith and Credit for Child Support Orders Act, Pub. L. No. 103-383, $\S 2(a)(3)(E), 108$ Stat. 4063, 4064 (1994). It could be argued that the passage of this Act was beyond the scope of Congress's authority in the area of state-created child support orders. Critics of the CSRA could say that Congress, in effect, assumes jurisdiction through this Act over conflicting state orders and decides which one should be enforced. Federal involvement on this scale has been rejected in other full faith and credit situations. See, e.g., Thompson v. Thompson, 484 U.S. 174, 187 (1988) (holding that 28 U.S.C. $\$ 1738$ B, the Parental Kidnapping Prevention Act, does not create a federal cause of action to determine which state order is valid when there are conflicting state orders).

${ }^{150}$ See UNIF. ChILD CuSTOdY JURISDiCTION AcT $\$ 3,9$ U.L.A. pt. I, at 143 (1968) (establishing a system that gives continuing exclusive jurisdiction over a child's custody to a court of one state and requires other state courts to yield to that court's jurisdiction unless specific requirements are met). UCCJA has been adopted by all 50 states, as well as by the District of Columbia. See Table of Jurisdictions, 9 U.L.A. pt. I, at 115.

${ }^{151}$ See 28 U.S.C. $\$ 1738 \mathrm{~B}(\mathrm{e})$ (1994).

152 See LeNORE J. WEITZMAN, THE DIVORCE REVOlUtion: THE UNEXPECTED SOCIAL. AND ECONOMIC CONSEQUENCES FOR WOMEN AND CHILDREN IN AMERICA 436-37 app. C (1985) (listing the jurisdictions where past-due child support awards may be modified: Alabama, Arkansas, Connecticut, Delaware, Florida, Georgia, Hawaii, Indiana, Iowa, Kansas, Kentucky, Maine, Maryland, Massachusetts, Michigan, Minnesota, Mississippi, Missouri, Nebraska, New Hampshire, New Jersey, New Mexico, New York, North Carolina, North Dakota, Ohio, Oklahoma, Pennsylvania, Rhode Island, South Carolina, South Dakota, Tennessee, Utah, Vermont, Virginia, Washington, West Virginia, Wisconsin, Wyoming, and Washington, D.C.). These states' laws require a custodial parent to take an extra step in the already timeconsuming process of attempting to enforce a child support judgment. In these states, the parent must obtain a final judgment on the past-due amount from the state court in order for the support order to be final and enforceable. See 2 MARYGOLD S. MELII ET AL., ALIMONY, CHILd SUPPORT, COUNSEL FEES: AWARd, MODIFICATION \& ENFORCEMENT § 18.06[2], at 18-62 to 18-64 (1992). 


\section{b. Delay of Adoption}

Although the innovations of UIFSA promise to alleviate some of the problems faced by the states who were operating under the URESA and RURESA systems, these improvements will take some time to become effective. One reason for the delay in improvement is simply that UIFSA has yet to be universally adopted. More than three years after it was approved by the American Bar Association and the Commissioners, only thirty percent of American jurisdictions had adopted it. ${ }^{153}$ This delay on the part of state legislatures may simply be the result of busy state dockets, but it may also be an indication that a majority of states do not agree with the policies advanced by UIFSA. Even if UIFSA is eventually adopted by all United States jurisdictions, it may not be enacted in exactly the same form, thus frustrating some of the benefits of a uniform law. Although they are discouraged from substantially changing the provisions of uniform acts, ${ }^{154}$ state legislatures often do so anyway. ${ }^{155}$ Of the twenty states that have adopted UIFSA to date, four have made changes that have more than a de minimis effect. ${ }^{156}$ Also, because UIFSA is enacted as state law, and as such may not be conclusively construed by the federal courts, ${ }^{157}$ each

${ }^{153}$ See supra note 128 and accompanying text.

${ }^{154}$ See Commissioners on UNiform STATE LAwS, 1993-94 Reference Book 3 (noting that it is the Conference's goal to alleviate problems created by the nonuniformity in state law when transactions, services, and people cross state lines); see also REVISED UNIF. RECIPROCAL ENFORCEMENT OF SUPPORT ACT § 41, 9B U.L.A. 550 (1968) (explaining that this "Act shall be so construed as to effectuate its general purpose to make uniform the law of those states which enact it ${ }^{n}$ ).

${ }^{155}$ For example, Arkansas, Florida, California, Georgia, Illinois, Ohio, Rhode Island, South Carolina, and Virginia all substantially modified RURESA upon adoption. See REVISEd UNIF. RECIPROCAL ENFORCEMENT OF SUPPORT ACT, General Statutory Notes, 9B U.L.A. 383 (1968).

${ }^{156}$ See ARIZ. REv. STAT. ANN. $§ 12-1721$ to $12-1756$ (1994 \& Supp. 1995) (adopting UIFSA, but failing to repeal RURESA, so that RURESA can be used when Arizona receives a case from an initiating state that has not adopted UIFSA); CoLO. REv. STAT. ANN. \$§ 14-5-101 to 14-5-1007 (West Supp. 1994) (enacting a different part 10, §§ 14-5-1001 to 14-5-1006); MINN. STAT. ANN. §§ 518C.101 to 518C.902 (West Supp. 1995) (adding a new section in 518C.9011); S.C. CODE ANN. \$§ 20-7-960 to 20-7-1170 (Law. Co-op. 1976 \& Supp. 1994) (adding a new section regarding parentage, § 20-7-1158); see also UNIF. INTERSTATE FAMILY SUPPORT ACT, General Statutory Note, 9 U.L.A. pt. I, at 233 (1992) (explaining that "[w]hile the Arizona act is a substantial adoption of the major provisions of the Uniform Act, it departs from the official text in such manner that the various instances of substitution, omission and additional matter cannot be clearly indicated by statutory notes").

${ }^{157}$ See PAUl M. BATOR ET AL., HART \& WECHSLER'S The FEDERAL. CourTS AND THE FEDERAL SYSTEM 789-91 (3d ed. 1988) (explaining that federal courts must look to 
state's courts may choose to interpret its provisions in slightly different ways that may be substantial enough to cause confusion to participants in multistate proceedings.

\section{c. Jurisdictional Problems}

One other procedural problem with leaving child support enforcement to the states, until UIFSA takes effect everywhere, is that nonuniform long-arm jurisdictional statutes provide states with questionable jurisdiction over out-of-state obligors. Even if the custodial parent may resort to a two-state proceeding under RURESA, ${ }^{158}$ that proceeding will be more time-consuming and expensive than if the custodial parent was able to sue on the support obligation in her own state. ${ }^{159}$ Moreover, during the time spent in litigation, the custodial parent will not receive the support due to her child. ${ }^{160}$ Custodial parents who live in states that lack minimum contacts with the noncustodial parent ${ }^{161}$ are particularly vulnerable to delayed enforcement of support orders. ${ }^{162}$ This was

lower state courts' interpretations of state law when the state's highest court has not spoken to the state law issue in question).

${ }^{158}$ See supra part II.A.2.a.

${ }^{159}$ See Mark S. Guralnick, INTERstate Child Custody Litigation 1-2 (1993) (discussing the time-consuming aspects of interstate custody litigation that also occur in interstate support litigation).

${ }^{160}$ Child support obligations arise only when a court enters an order specifying the amount to be paid, see In re Marriage of Klein, 671 P.2d 1345, 1348 (Colo. Ct. App. 1983), but some states may allow support to be awarded retroactively to the date of the parents' separation, see Crabtree v. Crabtree, 651 P.2d 29, 31-32 (Mont. 1982). Although not within the scope of this Comment, there is a related problem that the jurisdictional requirements for child custody and child support cases may be different. Because parents may be reluctant to proceed simultaneously in different states, they may face difficulty in finding a convenient state that will exercise jurisdiction over both issues. See Linda M. DeMelis, Note, Interstate Child Custody and the Parental Kidnapping Prevention Act: The Continuing Search for a National Standard, 45 HASTINGS L.J. 1329, 1352-53 (1994).

${ }_{161}$ The doctrine of minimum contacts was articulated in International Shoe Co. v. Washington, 326 U.S. 310, 319 (1945) (describing the constitutionally permissible minimum contacts that a state court must have in order to assert jurisdiction over a nonresident of the state as dependent upon the "quality and nature of the activity"); cf. E.R. Lanier, Connecting Defendant's Contact and Plaintiff's Claim: The Doctrine of Specific Jurisdiction and the Matrimonial Domicile Provisions of the Georgia Long-Arm Statute, 11 GA. ST. U. L. REv. 303, 310-15 (1995) (analyzing the necessary degree of connection between a plaintiff's claim and a defendant's contacts under the Georgia long-arm statute for family relations issues).

${ }_{162}$ See Carol S. Bruch, Statutory Reform of Constitutional Doctrine: Fitting International Shoe to Family Law, 28 U.C. DAVIS L. REV. 1047, 1054 (1995); see also Heather M. Lammers, Note, Murphy v. Basile: Successful Abandonment By the Judicial 
the situation in Kulko $v$. Superior Court, ${ }^{163}$ in which the United States Supreme Gourt held that a California court could not assert jurisdiction over a nonresident noncustodial father who refused to pay child support, even though the child lived in California with her mother under an agreement that the father had approved. ${ }^{164}$

As an alternative to making these parents depend upon RURESA for a remedy, it has been suggested that state legislatures accept the invitation of the Supreme Court in Kulko to broaden the scope of their jurisdictional authority by making specific findings about the importance of allowing a child's home state to have jurisdiction over matters concerning that child's support and custody. ${ }^{165}$ The Clinton Administration supported a child-based jurisdictional standard in its 1994 proposed changes to welfare. ${ }^{166}$ The proposal would have required states, as a condition of their AFDC funding, to adopt UIFSA, amended to establish the presumption that a state has jurisdiction over both parents if the child is a state resident. ${ }^{167}$

The criminal provisions of the CSRA would provide an enforcement mechanism that is not subject to dismissal for lack of subject matter jurisdiction. ${ }^{168}$ Since relief under the statute is pursued in federal court ${ }^{169}$ and the operation of federal law is not limited by state lines, ${ }^{170}$ the question is reduced to which federal district

System of a Mother Asserting In Personam Jurisdiction Against a Nonresident Putative Father, 40 S.D. L. REv. 546, 546 (1995) (arguing that the South Dakota Supreme Court's refusal to exercise jurisdiction over a nonresident putative father when the child lived in South Dakota was, in effect, judicial encouragement to the father not to pay child support).

${ }^{163} 436$ U.S. 84 (1978).

${ }^{164}$ See id. at 87-88 (explaining that the father "bought his daughter a one-way plane ticket" to California and she left, "taking her clothing with her"). The Court later recharacterized the father's act as "connot[ing] no intent to obtain or expectancy of receiving a corresponding benefit in [California]." Id. at 101. The Court ignored the reality that the daughter would receive many benefits from the State of California and that the father intended for her to receive those benefits. See id. at 89 .

${ }^{165}$ See Bruch, supra note 162, at 1054-56 (urging a stronger legislative response to Kulko and arguing that if owning a piece of land is enough to give the state containing the land jurisdiction over a nonresident landowner in a suit concerning an accident on that land, then a child's presence in a state should be sufficient to give that state jurisdiction over a nonresident parent in a suit concerning the survival and maintenance of the child).

${ }^{166}$ See id. at 1057 n.43.

${ }^{167}$ See id.

${ }^{168}$ See 28 U.S.C. $\$ 1331$ (1994) (providing federal courts with jurisdiction over cases "arising under" federal law).

${ }^{169}$ See id.

${ }^{170}$ The Supremacy Clause of the Constitution provides that federal law is applicable in every state. See U.S. CONST. art. VI, cl. 2. 
court will have proper venue to hear the case. Also, since the sanctions offered by the CSRA are criminal, the government, and not the custodial parent, would bear the substantial costs of litigation required to secure payment of the unmet support obligation. ${ }^{171}$

\section{Practical Problems}

One of the most obvious problems, and the most impervious to legal solution, faced by the custodial parent seeking to enforce a support order is the difficulty involved in finding a noncustodial parent who does not want to be located. ${ }^{172}$ Unless the custodial parent has the resources to employ an investigating service, which is especially unlikely for custodial parents who receive public assistance, the custodial parent must rely on information provided by the noncustodial parent or his family and acquaintances to determine his whereabouts. Even if the noncustodial parent is eventually located, and the court of his state exercises jurisdiction over him, it still may be difficult to discover any financial assets that may be used to calculate or satisfy a child support award. ${ }^{173}$

Gustodial parents who receive AFDC may turn to their state Title IV-D agency for free assistance in enforcing their child support awards, and other custodial parents may invoke state aid for a nominal fee. ${ }^{174}$ Title IV-D agencies, although mandated by the federal government, are administered by the states under a set of administrative regulations promulgated by the Office of Child Support Enforcement ("OCSE"), a division of the Department of Health and Human Services. ${ }^{175}$ Although these agencies seem

171 See 1 Barry H. Frank et al., Alimony, Child Support, Counsel Fees: AWARD, MODIFICATION \& ENFORCEMENT § 11.02[2], at 11-19 (1992) ("[M]aking nonsupport a crime has the advantage of providing the nonsupported child with the help of the public prosecutor in bringing an action and in searching out the defaulting parent.").

172 See 140 CONG. REC. S7269, S7356 (daily ed. June 21, 1994) (Work and Responsibility Act of 1994 fact sheet).

${ }^{173}$ See GuRALNICK, supra note 159, at 2 (noting that interstate child custody litigation, which is procedurally similar to child support litigation, is "an imperfect mélange of complaints . . . timed strategically to vest, or divest, parties of jurisdiction; ex parte appearances; . . . costly interstate travel; . . . conflicting court orders; and the hide-and-seek relationship between parents and children on the move").

${ }^{134}$ See supra note 36 and accompanying text; see also 42 U.S.C. § 654(6) (1994) (setting forth the procedure by which non-AFDC eligible parents may obtain state aid).

${ }^{175}$ See 45 C.F.R. $§ 301-307$ (1995). 
effective in theory, they are almost universally described as failures, perhaps because too many parents attempt to take advantage of them. ${ }^{176}$ One scholar commented, “ $[t]$ he system was thwarted by even more bureaucracy, thick practice manuals, a case overload growing at an alarming rate, and technicalities. The state child support agencies were underfunded and understaffed to handle the rapidly increasing volume of cases. ${ }^{n 177}$ The amendments to the OCSE system in 1984, 1986, and 1988 had little substantive effect on the ineffectiveness of Title IV-D agencies in the states. ${ }^{178}$ According to General Accounting Office estimates, the average fulltime caseworker in a state Title IV-D agency handles over 1000 cases at the same time. ${ }^{179}$

Another impediment to the collection of child support debt exists for those custodial parents who have been successful in locating the noncustodial parent and bringing him to court. There is a feeling among many custodial parents that judges are "unsympathetic and impatient with their request[s]. ${ }^{180}$ In testimony before Congress in 1983, the president of the Organization for the Enforcement of Child Support ("OECS") stated that "[i]t is easy for a parent who is in arrears to make a rather lame excuse in front of a lenient judge and be let off with a warning." 181 Although these reports of widespread dissatisfaction are somewhat dated, it is unlikely that all of those attitudes would have been eradicated from the system in the space of ten years.

A final uncertainty in the enforcement process is the possible modification of awards because of different standards for calculating the amount of child support owed. As yet, there are no federal

${ }^{176}$ But see TAKAS, supra note 125 , at 7 (noting that state Title IV-D offices will continue to improve their services and may be more effective at collecting support than a private attorney).

177 Calhoun, supra note 31 , at 931 (citations omitted).

${ }^{178}$ See Rhonda McMillion, Child Care: Congress Seeks Stronger Interstate Child Support System, 79 A.B.A. J., Aug. 1993, at 107, 107 (noting that Title IV-D's flexibility in allowing differences between state procedures has caused difficulty in interstate cases); Harry B. O'Donnell IV, Note, Title I of the Family Support Act of 1988-The Quest for Effective National Child Support Enforcement Continues, 29 J. FAM. L. 149, 154-55 (1990) (noting that Title IV-D agencies did not perform as well as expected).

179 See Margaret C. Haynes, Child Support and the Courts in the Year 2000, 17 АM. J. TRIAL ADVOC. 693, 695 (1994) (discussing the challenges facing state agencies that have increasing caseloads and no corresponding increase in their budgets).

${ }^{180}$ Weitzman, supra note 30 , at 267.

${ }^{181}$ Child Support Enforcement Legislation: Hearings Before the Subcomm. on Public Assistance and Unemployment Compensation of the House Comm. on Ways and Means, 98th Cong., 1st Sess. 111 (1983) (statement of Elaine M. Fromm, President, OECS). 
guidelines on the calculation of support amounts, so states differ on how they make their calculations. ${ }^{182}$

\section{The Benefits of Federal Legislation and a Description of Recent Federal Laws Affecting Enforcement}

The criminal provisions of the CSRA ${ }^{183}$ have been helpful in solving all of the problems with state enforcement. First, in a federal criminal prosecution, the Department of Justice's investigative resources are added to those of overburdened state Title IV-D agencies. ${ }^{184}$ Although the federal government is unable to assist in every interstate case, its involvement dramatically increases the likelihood of successfully prosecuting the most serious cases; after less than a year of prosecutions under the statute, federal officials have commenced suits to recover well over one million dollars of unpaid child support. ${ }^{185}$ The possibility of federal prosecution may also act as a strong incentive for obligors to become current on large overdue child support obligations. The Department of Justice has committed itself to "aggressive investigation and prosecution" targeted at the most egregious violators, and hopes to prosecute about 200 new cases per year. ${ }^{186}$ While these cases represent only a fraction of the millions of parents who fail to pay child support, they will increase the attention given to the child support problem and will act as a reminder that evading child support payments is a serious matter that can no longer be so easily avoided. The increased attention and devotion of resources to child support cases

${ }^{182}$ See Haynes, supra note 179, at 700-03 (explaining the goals and purposes of the National Child Support Guidelines Commission).

${ }^{183}$ See, e.g., supra note 69 (setting out one criminal provision, $\$ 228$, of the CSRA).

184 When the government prosecutes a criminal case, it may often be obligated to pay the expenses associated with investigation and litigation. See FED. R. CRIM. P. 15(c).

${ }^{185}$ From the reported cases alone, it is clear that the government's claims have approached the million dollar mark. Jeffrey Nichols alone owes over half a million dollars. See Sixty Minutes, supra note 1. Patrick Law owes $\$ 140,000$. See Deadbeat Dad, supra note 15, at A3. Steven Parker owes over $\$ 25,000$. See United States v. Parker, 911 F. Supp. 830, 832 (E.D. Pa. 1995). Donald Schroeder owes approximately $\$ 24,000$. See United States v. Schroeder, 894 F. Supp. 360, 362 (D. Ariz. 1995). Mark Hopper is at least $\$ 5335$ in arrears, although he may owe as much as $\$ 24,000$. See United States v. Hopper, 899 F. Supp. 389, 391 (S.D. Ind. 1995). Allan Mussari owes $\$ 40,385$. See United States v. Mussari, 894 F. Supp. 1360, 1361 (D. Ariz. 1995). The published opinions do not indicate the amounts owed by Samuel Sage, John Kegel, Ricky Hampshire, James Murphy, or Keith Bailey.

${ }^{186}$ Deadbeat Dad Enforcement: DOJ on Tightrope, DEP'T JUST. ALERT, Jan. 2-16, 1995, at 2, 2 [hereinafter Deadbeat Dad Enforcement]. 
at the federal level will hopefully encourage state court judges to be less lenient in their dealings with child support debtors.

In the last five years, Congress has focused more extensively on the growing problem of child support enforcement and its impact on federal and state welfare expenditures. Several pieces of proposed and enacted federal legislation describe innovative approaches to making the enforcement process less time-consuming, less burdensome, and more effective. ${ }^{187}$ But the CSRA, by attaching criminal penalties to the failure to pay support obligations, is indicative of Congress's strengthened resolve to combat the growing balance of unpaid support. ${ }^{188}$ The CSRA is only one part of a group of laws designed to aid states in their ability to enforce child support obligations in other states. ${ }^{189}$ When added to the arsenal of these other federal laws, the criminal provisions of the CSRA will provide an effective deterrent to nonpayment. Without the CSRA, the noncustodial parent is obligated to pay only the overdue amount of support and potentially some accrued interest, but is not subject to punitive sanctions. ${ }^{190}$ Therefore, there are no additional incentives for the noncustodial parent to pay on time if all he will eventually pay is the amount due. In combination, the criminal provisions of the CSRA and the other federal laws will likely increase the percentage of orders that are enforced. ${ }^{191}$

Arguably, the most significant reforms are those associated with tax refund withholding and wage garnishment. The Internal Revenue Service has been withholding federal tax refunds from nonsupporting parents for fourteen years, ${ }^{192}$ and the 1984 amendments to Title IV-D enable state tax refunds to be similarly with-

${ }^{187}$ See infra notes $192-205$ and accompanying text.

${ }^{188}$ See generally H.R. REP. No. 771, 102d Cong., 2d Sess. 1 (1992) (imposing a "criminal penalty for flight to avoid payment of arrearages in child support").

${ }^{189}$ Even without the criminal provisions of the CSRA, federal involvement in interstate support enforcement would be substantial; most federal involvement is in the administration of state agencies operating under the Department of Health, Education and Welfare. See supra notes 35-36, 175-79 and accompanying text (discussing the role of state agencies established by Title IV-D of the Social Security Act).

190 See Ira M. Ellman et al., Family law: Cases, Text, Problems 395 (1986) (explaining that in civil contempt cases, the obligor may avoid punishment simply by paying his accrued debt).

191 See Haynes, supra note 179, at 718 (concluding that recent federal and state legislation will make the child support enforcement system more efficient).

192 See Omnibus Budget Reconciliation Act of 1981, Pub. L. No. 97-35, tit. XXIII, § 2331(a), 95 Stat. 357, 860-61 (codified as amended at 42 U.S.C. $\$ 664$ (1994)). 
held. ${ }^{193}$ The federal government requires the states, as a condition of their AFDC funding, to establish procedures by which "any refund of State income tax which would otherwise be payable to an absent parent will be reduced ... by the amount of any overdue support." ${ }^{194}$ These and later amendments also require states to allow income-withholding so that support payments can be directly deducted from the obligor's income. ${ }^{195}$ Congress found that income-withholding provisions are among the "most effective, efficient and low-cost techniques for bringing child support obligations into paying status and keeping them there" because "[d]educting current support obligations from paychecks keeps support payments current without any effort on the part of the obligor and insures that the support obligation will come before other expenditures." 196

The Child Support Economic Security Act of $1993,{ }^{197}$ which was stalled in committee and never passed by the 103rd Congress, would have made all income (including lottery winnings, insurance policy benefits, and court-awarded judgments, but not public assistance) subject to withholding for child support. ${ }^{198}$ Also, the bill would have required that states deny all professional licenses to those more than $\$ 1000$ in arrears on support payments who have not made a "good faith effort" to pay their debt. ${ }^{199}$ Furthermore, the bill would have required reporting of past-due child support obligations to consumer reporting agencies for individuals with overdue amounts in excess of the monthly support payment owed. ${ }^{200}$ Perhaps most significantly, the bill would have imposed deadlines for interstate cases on state enforcement agencies to prevent the cases from dragging on indefinitely. ${ }^{201}$

The Interstate Child Support Enforcement Act, ${ }^{202}$ which was introduced in 1993 and also stalled in committee, would have required the states to adopt UIFSA, primarily because of its continuing exclusive jurisdiction principle. ${ }^{203}$ Additionally, the

\footnotetext{
${ }^{193}$ See 42 U.S.C. $\$ 666(a)(3)(A)(1994)$.

${ }^{194} \mathrm{Id}$.

${ }^{195}$ See 42 U.S.C. § 666(a)(8) (1994).

${ }^{196}$ H.R. REP. No. 527, 98th Cong., 1st Sess., pt. IV, at 31 (1983).

${ }^{197}$ H.R. 915, 103d Cong,, 1st Sess.

${ }^{198}$ See id. $\$ 104$.

${ }^{199}$ See id. $\$ 105$.

${ }^{200}$ See id. \$ 106.

${ }^{201}$ See id. \$ 111.

${ }^{202}$ H.R. 1600, 103d Cong., 1st Sess. (1993); S. 689, 103d Cong., 1st Sess. (1993).

${ }^{20 \$}$ See H.R. 1600, § 424; S. 689, § 424.
} 
bill would have strengthened the state income withholding provisions by changing the W-4 income tax withholding form to require new employees to reveal existing support obligations. ${ }^{204}$ It also would have expanded the use of the Federal Parent Locator System, a set of databases that maintain records of child support orders and parents' locations. ${ }^{205}$

Thus, several weapons in the proposed federal arsenal of child support devices were never passed by Congress, and the problems of children living without parental support remains. The criminal provisions of the CSRA should be seen as a major facet of the federal initiative against children living in poverty. That initiative may be jeopardized if the criminal provisions are struck down as being constitutionally infirm.

\section{The Constitutional Debate}

\section{A. The Commerce Clause Problem}

In analyzing how Lopez applies to the criminal provisions of the CSRA, the federal district courts have focused primarily on four aspects of the Lopez decision: (1) the Court's discussion of the absence of a jurisdictional element; (2) the nature of the activity prohibited; (3) the legislative history showing congressional purpose in creating a federal criminal statute; and (4) the doctrines of federalism and comity that underlie the conflict between state and federal authority. ${ }^{206}$ Four courts utilized these elements to reach the conclusion that $\S 228$ of the CSRA was unconstitutional, while five courts reached the opposite conclusion. ${ }^{207}$ In the rash of litigation that has sprung up after Lopez over the constitutionality of a variety of federal criminal statutes, these elements have been at the center of the courts' analyses. ${ }^{208}$ Although no circuit court has yet dealt with the question of $\S 228$ 's constitutionality, several circuits have declined to extend the reasoning of Lopez and have

${ }^{204}$ See H.R. 1600, \$ 402(a)(2).

205 See id. $\$ \$ 101,402$.

${ }^{206}$ See generally United States v. Lopez, 115 S. Ct. 1624 (1995) (holding that a provision of the Gun-Free School Zones Act of 1990 is invalid as beyond Congress's Commerce Clause power).

${ }^{207}$ See supra part I.B (discussing the federal district court split).

${ }^{208}$ See, e.g., United States v. Pappadopoulos, 64 F.3d 522, 525-28 (9th Cir. 1995) (analyzing the requirements of a jurisdictional element, an effect on commerce, and concerns about federalism in upholding the federal arson statute, 18 U.S.C. $§ 844(i)$, as being constitutional and within Congress's powers under the Commerce Clause). 
upheld federal statutes criminalizing arson, carjacking, and the possession of firearms. ${ }^{209}$ In the October 1995 term, the Supreme Court refused to reevaluate its Lopez analysis in light of these challenges, although Justice Thomas has indicated a desire to extend its reasoning. ${ }^{210}$ The following analysis examines in detail each contested element of the Lopez holding.

\section{Jurisdictional Elements}

The Lopez Court explained that one of the fundamental problems with § 922(q) of the Gun-Free School Zones Act of 1990 $\left(" \S 922(q)^{n}\right)^{211}$ was that it contained "no jurisdictional element which would ensure, through case-by-case inquiry, that the firearm possession in question affects interstate commerce. ${ }^{\text {212 }}$ In further explaining what it meant by a jurisdictional element, the Court analogized to United States v. Bass, ${ }^{213}$ wherein the Court held that in order to convict a person under a statute that made it a crime for a felon to possess a firearm that is in commerce or affecting commerce, ${ }^{n 214}$ the government must specifically prove an "additional nexus to interstate commerce." ${ }^{215}$ The Lopez Court struck down $\S 922(q)$ because it contained no specific language mandating a connection between the possessed firearm and movement in interstate commerce. ${ }^{216}$

In contrast to the statute at issue in Lopez, $\S 228(a)$ of the CSRA specifically states that an interstate connection must exist by limiting the federal offense to cases where the support obligation is "with

${ }^{209}$ See United States v. Sherlin, 67 F.3d 1208, 1213-14 (6th Cir. 1995) (upholding the federal arson statute), cert. denied, $116 \mathrm{~S}$. Ct. 795 (1996); United States v. Bishop, 66 F.3d 569, 576 (3d Cir.) (upholding the federal carjacking statute), cert. denied, 116 S. Ct. 681 (1995); United States v. Rankin, 64 F.3d 338, 339 (8th Cir.) (upholding the federal possession of weapons statute), cert. denied, 116 S. Ct. 577 (1995); United States v. Dodge, 61 F.3d 142, 145 (2d Cir.) (same), cert. denied, 116 S. Ct. 428 (1995).

${ }^{210}$ In dissenting from the denial of certiorari in Leslie Salt Co. v. United States, 55 F. 3d 1388 (9th Cir.), cert. denied, 116 S. Ct. 407 (1995), Justice Thomas indicated that he would like to revisit the Lopez analysis. See Cargill, Inc. v. United States, 116 S. Ct. 407, 409 (1995).

211 18 U.S.C. $\$ 922(q)(1994)$.

${ }^{212}$ United States v. Lopez, 115 S. Ct. 1624, 1631 (1995).

213404 U.S. 336 (1971).

${ }^{214}$ Id. at 337 (citing 18 U.S.C. $\$ 1202(a)$, which now exists in modified form as 18 U.S.C. \$ 922(g) (1994)).

${ }^{215}$ Lopez, 115 S. Ct. at 1631 (emphasis added).

${ }^{216}$ See id.; see also 18 U.S.C. \$ 922(q)(2)(A) (1994) (making it a federal crime " for any individual knowingly to possess a firearm at a place that the individual knows, or has reasonable cause to believe, is a school zone ${ }^{n}$ ). 
respect to a child who resides in another State. ${ }^{217}$ The main point of contention between the lower courts is whether this language provides the additional nexus to interstate commerce that Lopez requires. ${ }^{218}$ The courts that found the statute to be constitutional agree that even though $\S 228$ does not specifically state that interstate commerce must be affected, the limitation of the statute to interstate cases is sufficient to ensure that only cases that affect the redistribution of financial assets between states will be covered. ${ }^{219}$ The requirement that the nonsupporting parent and the child live in different states will prevent the federal government from interfering in the domestic relations concerns of one state, while invoking federal aid to solve enforcement problems that occur because of the jurisdictional limits on state authority. ${ }^{220}$ In comparison to the jurisdictional elements held to be sufficient by other courts interpreting Lopez, the interstate requirement of $\S 228$ seems clearly sufficient. ${ }^{221}$

The courts finding $\S 228$ unconstitutional attacked the overbreadth of the interstate requirement, arguing that because Congress's purpose was to "impose a criminal penalty for flight to avoid payment of arrearages in child support,' the jurisdictional element is invalid because it is not narrowly tailored to meet those goals. ${ }^{222}$ This logic is difficult to follow because it implicitly

${ }^{217} 18$ U.S.C. $\$ 228(a)$ (1994).

${ }^{218}$ See Lopez, 115 S. Ct. at 1631.

${ }^{219}$ See, e.g., United States v. Sage, 906 F. Supp. 84, 91-92 (D. Conn. 1995) (asserting that "[b]y limiting regulation to interstate payments only a nexus to interstate commerce is assured," because the redirection of money across state lines also redirects the interstate market demand for goods).

${ }^{220}$ See United States v. Kegel, No. 95-300-CR-T-21(E), 1996 WL 69725, at *2 (M.D. Fla. Feb. 13, 1996); United States v. Hopper, 899 F. Supp. 389, 393 (S.D. Ind. 1995); United States v. Murphy, 893 F. Supp. 614, 616 (W.D. Va. 1995); United States v. Hampshire, 892 F. Supp. 1327, 1329 (D. Kan. 1995).

${ }_{221}$ See United States v. Wilks, 58 F.3d 1518, 1521 (10th Cir. 1995) (upholding 18 U.S.C. $\$ 922(0)$, even though the statute's only jurisdictional basis for making it a crime for any person to transfer or possess a machine gun was premised upon the legislative history of the Act, which established that machine guns "by their nature are 'a commodity . . . transferred across state lines for profit"' (quoting United States v. Hunter, 843 F. Supp. 235, 249 (E.D. Mich. 1994))); United States v. Hanna, 55 F.3d 1456, 1461-62 (9th Cir. 1995) (upholding the validity of the jurisdictional element of 18 U.S.C. $\$ 922(\mathrm{~g})(1)$, which required the possession of a firearm in or affecting commerce); United States v. Brown, 893 F. Supp. 11, 12 (M.D.N.C. 1995) (same); $c f$. United States v. Pappadopoulos, 64 F.3d 522, 528 (9th Cir. 1995) (holding that the jurisdictional element of the federal arson statute is not satisfied by a private residence whose only connection to interstate commerce is that it receives gas that comes from out of state).

${ }^{222}$ United States v. Mussari, 894 F. Supp. 1360, 1364 (D. Ariz. 1995) (quoting H.R. 
invokes the requirements of heightened scrutiny analysis ${ }^{223}$ for infringements of the right to interstate travel. Even assuming that the Schroeder and Mussari courts are arguing that $\S 228$ is unconstitutional because it interferes with the right to interstate travel and is not narrowly tailored to achieve its objective, ${ }^{224}$ and is not simply confusing a narrow-tailoring test with the Lopez requirement of an additional nexus to interstate commerce, ${ }^{225}$ this logic remains unpersuasive. The compelling governmental interest sought to be advanced by the statute is the payment of delinquent child support obligations. Because state enforcement has been shown to be ineffective in all interstate cases, even where the interstate tie has been created by the movement of the custodial parent, ${ }^{226}$ the potential for federal intervention in all interstate cases is necessary to achieve the stated objective. Otherwise, the custodial parent's right to interstate travel would be burdened if her ability to collect

REP. No. 771, 102d Cong., 2d Sess. 1 (1992)); United States v. Schroeder, 894 F. Supp. 360, 365 (D. Ariz. 1995) (same).

${ }_{223}$ Heightened scrutiny is the test applied to judge the constitutionality of legislation that burdens fundamental rights or is based on suspect classifications. See TRIBE, supra note $62, \S 16-6$, at 1451 . When strict scrutiny is applied, the classification will be upheld only if it is necessary to promote a compelling governmental interest. See id. $\S 16-7$, at 1454 . The legislation must be narrowly tailored to meet its stated objective. See, e.g., Richmond v. J.A. Croson Co., 488 U.S. 469, 505, 508 (1989) (holding Richmond's set-aside program for minority contractors to be unconstitutional because the city "failed to demonstrate a compelling interest in apportioning public contracting opportunities on the basis of race" and failed to show that the program was "narrowly tailored to remedy the effects of prior discrimination").

${ }^{224}$ When legislation conditions the award of benefits or the deprivation of rights based on factors that interfere with a United States citizen's right to travel or move interstate, the strict scrutiny requirements of the Fourteenth Amendment's Equal Protection Clause are invoked. See TRIBE, supra note 62, $\$ 16-8$, at 1455 . Although the Constitution does not specifically mention the right to interstate travel, some cases have held that it is a fundamental right deserving of strict scrutiny protection. See, e.g., Shapiro v. Thompson, 394 U.S. 618, 634-38 (1969) (holding that a one-year residency requirement for the receipt of welfare violates the constitutional right to travel from state to state and must be judged by strict scrutiny standards). Other cases have described the right to interstate travel as one of the "privileges and immunities" of U.S. citizenship that is protected against state interference by the Equal Protection Clause of the Fourteenth Amendment. See, e.g., Doe v. Bolton, 410 U.S. 179, 200 (1973) (striking down the residency requirement of a Georgia abortion statute because it violated the Privileges and Immunities Clause of Article IV, $\$ 2$ ).

${ }^{225}$ See United States v. Lopez, 115 S. Ct. 1624, 1631 (1995).

${ }^{226}$ See supra part II.B; $c f$. United States v. Kegel, No. 95-300-CR-T-21(E), 1996 WL 69725 , at $* 3$ (M.D. Fla. Feb. 13, 1996) (finding that as long as the parents are in different states and the obligor-parent fails to make support payments, the concerns addressed by the CSRA are raised, regardless of the motivations that prompted either parent to move out of state). 
child support were to be hampered by her decision to move to a different state. ${ }^{227}$ Moreover, the federal law is not invoked merely by a child support obligor's decision to move interstate; he must also willfully engage in the culpable behavior of failing to pay his child support debts.

Even if the Schroeder and Mussari courts are correct in stating that the language of the statute reaches more parents than Congress intended because of its failure to differentiate situations where the custodial parent moves interstate, ${ }^{228}$ that argument does not affect the Lopez jurisdictional requirement issue, for Congress did require an interstate connection for each case that will be prosecuted under $\S 228 .{ }^{229}$ Additionally, the Schroeder and Mussari courts seem to engage in selective reading of the statute's legislative history by citing the purpose identified at the beginning of the Judiciary Committee's report, ${ }^{230}$ but ignoring the more detailed explanation of the statute's purpose and desired effect. ${ }^{231}$ The Committee's report focuses not on the need to punish the nonsupporting parent's flight, but instead on the need to punish those who fail to pay their support obligations. It recognizes that interstate collection poses many.procedural obstacles to effective collection, especially for the "hard core' group of parents who flagrantly refuse to pay." 232

The Schroeder and Mussari courts also invoke a slippery slope argument to protest that allowing the jurisdictional element in $\S 228$ to stand "would result in unlimited Congressional power to regulate" without regard for subjects reserved for state control. ${ }^{233}$

${ }^{227}$ Cf. United States v. Kegel, No. 95-300-CR-T-21(E), 1996 WL 69725, al *3 (M.D. Fla. Feb. 13, 1996) ("However, the 'innocent' relocation to a different jurisdiction is no less an injurious use of the channels of interstate commerce than the intentional flight to avoid payment of child support obligations . ...").

${ }_{228}$ See United States v. Mussari, 894 F. Supp. 1360, 1364 (D. Ariz. 1995) (noting that, despite $\$ 228$ 's stated purpose of penalizing a parent's flight to avoid payment, the law nonetheless has "no intent to flee requirement" and applies broadly to "any parent who lives in a state different from the child, ${ }^{n}$ regardless of which parent created this difference); United States v. Schroeder, 894 F. Supp. 360, 365 (D. Ariz. 1995) (same).

${ }^{229}$ See 18 U.S.C. $\$ 228$ (a) (1994) (emphasizing that the statute is violated only when an obligation is owed to "a child who resides in another State").

${ }^{230}$ See Mussari, 894 F. Supp. at 1364 (stating that "the CSRA's legislative history specifically states that the purpose of [\$228] is to 'impose a criminal penalty for flight to avoid payment of arrearages in child support" (quoting H.R. REP. NO. 771, 102d Cong., 2d Sess. 1 (1992))); Schroeder, 894 F. Supp. at 365 (same).

${ }_{231}$ See H.R. REP. No. 771, 102d Cong., 2d Sess. 5-6 (1992).

232 Id. at 6.

${ }^{233}$ Schroeder, 894 F. Supp. 360, 365 (D. Ariz. 1995); see also Mussari, 894 F. Supp. 
This argument is not about whether Congress specified a necessary interstate connection in this particular statute, but touches on a more fundamental debate about whether the payment or nonpayment of child support can be considered commerce at all. ${ }^{234}$ Although the question of jurisdiction is different from the question of what constitutes commerce, the definition of a jurisdictional . element in Lopez invokes arguments about what constitutes commerce by using the word commerce. ${ }^{235}$ As recognized by the Parker court, a jurisdictional element ensuring that the statute affects interstate commerce is not satisfied by "the mere fact that an activity involves billions of dollars," for the statute must first be shown to regulate an activity that 'affects 'commerce' in the first place." 236 Therefore, it is necessary to examine what the lower courts understand to be the activities included in "commerce."

2. The Definition of "Commerce": What Is Economic Activity?

Much of Commerce Clause litigation has been an attempt to define the boundaries of the concept of "commerce."237 Because almost everything people do has an economic component, commerce, if defined simply as economic activity, could be practically limitless, and the power to regulate commerce could include the authority to regulate every decision people make. Although the limitation of Congress's authority to only those actions concerning interstate commerce may have been meaningful when the Constitution was written because localities were much more self-sufficient, that limitation has little force today in our increasingly national economy, where the ability to transport goods and information quickly between states is expanding continuously. ${ }^{238}$ Therefore,

1360,1364 (D. Ariz. 1995) (stating that upholding the jurisdictional element in $\$ 228$ "would in essence give Congress carte blanche to regulate any area it deemed appropriate, even if such area was traditionally one regulated by the States").

${ }^{234}$ See infra part III.A.2 (discussing some of the difficult issues involved in attempting to define "commerce" under the Commerce Clause).

${ }^{235}$ See United States v. Lopez, 115 S. Ct. 1624, 1631 (1995) (holding that § 922(q) "contains no jurisdictional element which would ensure, through case-by-case inquiry, that [the action in question] affects interstate commerce").

${ }^{286}$ United States v. Parker, 911 F. Supp. 830, 837 (E.D. Pa. 1995).

${ }^{237}$ See TRIBE, supra note 62, $\$ 5-4$, at 306-10 (discussing the changes in Supreme Court ideas about whether commerce should be evaluated formalistically or functionally).

${ }^{238}$ See World-Wide Volkswagen Corp. v. Woodson, 444 U.S. 286, 293 (1980) ("Today many commercial transactions touch two or more States and may involve parties separated by the full continent." (quoting McGee v. International Life Ins. 
if a principled distinction is to be drawn between activities that Congress may and may not regulate, some limitations must be placed on what constitutes commerce.

Defining commerce as commercial activity does not advance this analysis without a definition of "commercial." Classic commercial transactions are arm's-length transactions between businesses. Transactions in which only one party is in business, however, are also commercial. For example, when a consumer purchases a washing machine from an appliance dealer, the fact that the consumer is not acting for business purposes, but rather for personal reasons, does not make the transaction any less commercial. Similarly, a transaction in which neither party is "in the business" of selling washing machines is still commercial, even though a private market has replaced a public market. When the consumer decides to buy her neighbor's washing machine instead of going to a dealer, she has replaced a public market with a private market.

Having established that commercial activity extends beyond business transactions, it is necessary to designate the common element in these personal transactions that makes them commercial. I will define "commerce" as all transactions involving the exchange of value for an obligation, whether that obligation arises by status or by contract. Such a definition would clearly encompass the traditional business transaction without excluding the sale transaction between neighbors. Child support would also qualify as commerce under this definition because it is an exchange of value in the form of money that arises from the obligation of parentage.

The courts have mainly defined commerce by analogy to specific practices. In finding $\$ 922(q)$ unconstitutional, the Lopez Court held that the activity it regulated was not commerce:

Section $922(\mathrm{q})$ is a criminal statute that by its terms has nothing to do with "commerce" or any sort of economic enterprise, however broadly one might define those terms. Section $922(\mathrm{q})$ is not an essential part of a larger regulation of economic activity, in which

Co., 355 U.S. 220, 222-23 (1957))); Calhoun, supra note 31, at 924 (noting that "[c]hild support enforcement, which has traditionally been a state matter, has become national in scope because of the increasing mobility of American citizens").

${ }^{239}$ The following two paragraphs are my attempts to define "commerce" for use in the subsequent discussion. 
the regulatory scheme could be undercut unless the intrastate activity were regulated. ${ }^{240}$

The activity that Congress regulated in $\S 922(q)$ was the possession of a firearm in or near a school. ${ }^{241}$ In contrast to $\S 922(q)$, the activity regulated in $\S 228$-the failure to pay a debt owed to a child in another state-clearly has an economic component. In Lopez, the Court rejected the government's arguments that the possession of a firearm near a school is economic because it increases the potential for violent crime, which has a negative effect on the economy, and because it negatively impacts the educational environment and, thus, inhibits the development of children into educated and economically productive citizens. ${ }^{242}$ The Court explained that the government's cost-of-crime and national-productivity analyses would effectively abolish any limits on the definition of "commerce" and that the link between Lopez's activity and interstate commerce was too tenuous to justify Congress's regulation. ${ }^{243}$

In applying the Lopez analysis of what constitutes commerce to $\S 228$, the Schroeder court focused on the criminal nature of the penalties imposed by the statute and concluded that because some states have enacted their own criminal statutes in this area, there is no connection to interstate commerce. ${ }^{244}$ The Arizona court apparently chose words out of context to justify its otherwise unreasoned conclusion. Whether the states have chosen to impose their own criminal sanctions for the nonpayment of support has no bearing on whether Congress's regulation of nonpayment of support constitutes commerce.

The Schroeder court reached the heart of its commerce analysis in the context of discussing the CSRA's legislative history. ${ }^{245}$ Relying on a broad definition of commerce as "the commercial intercourse between nations, and parts of nations, in all its

${ }^{240}$ United States v. Lopez, 115 S. Ct. 1624, 1630-31 (1995).

${ }^{241}$ See 18 U.S.C. $\$ 922(q)$ (1994).

${ }^{242}$ See Lopez, 115 S. Ct. at 1632-33.

${ }^{243}$ See id. at 1632 (stating that if the Court "were to accept the Government's arguments, [it would be] hard-pressed to posit any activity by an individual that Congress is without power to regulate ${ }^{n}$ ).

244 See United States v. Mussari, 894 F. Supp. 1360, 1364 (D. Ariz. 1995) ("Therefore, the fact that this statute is a criminal statute aimed at an area of activity which has already been addressed by the States supports this court's finding that the CSRA is not substantially related to interstate commerce . ... ."); United States v. Schroeder, 894 F. Supp. 360, 364 (D. Ariz. 1995) (same).

245 See Mussari, 894 F. Supp. at 1366; Schroeder, 894 F. Supp. at 367. 
branches, ${ }^{246}$ the court concluded that "[t]here is no commercial intercourse involved in the collection of delinquent child support payments. If the collection of debt were sufficient to warrant federal criminal intervention, Congress would be able to legislate in virtually any area. ${ }^{247}$ The problem with this statement is that the court does not explain the reasoning of its conclusion; rather, the court uses a slippery slope argument to assert a policy goal of decreased governmental regulation.

The Parker court explains its similar conclusion in more detail. The government's brief in Parker advanced two arguments addressing why commerce is affected when child support obligations are unpaid. ${ }^{248}$ Under a "basic necessities" theory, the government argued that families that are denied child support may be unable to afford necessary goods and services, thus impacting commerce between the states. ${ }^{249}$ The government also contended that the failure to obtain court-ordered support forces many families to turn to federal welfare funding, and large welfare expenditures impact interstate commerce. ${ }^{250}$ Finding that, if the government's arguments were accepted, Congress would have the authority to prohibit "any crime that deprives another person of money," the court dismissed the arguments as being too attenuated to withstand scrutiny under Lopez. ${ }^{251}$ The Parker court's dismissal of these theories, however, may be attributable to a lack of concrete knowledge about the size of the interstate child support problem. Also, Parker's dismissal of the basic necessities theory hinges on the court's argument that such a rationale would allow Congress to regulate all theft and fraud that deprives individuals of resources. ${ }^{252}$ Because $\S 228$ reaches only one specific form of interstate "theft," and Congress has previously regulated other forms of interstate theft, such as mail fraud ${ }^{253}$ and wire fraud, ${ }^{254}$ the Parker argument is unpersuasive.

${ }^{246}$ Gibbons v. Ogden, 22 U.S. 1, 189-90 (1824).

${ }^{247}$ Mussari, 894 F. Supp. at 1366; Schroeder, 894 F. Supp. at 367.

${ }^{248}$ See United States v. Parker, 911 F. Supp. 830, 832 (E.D. Pa. 1995).

249 See $i d$. at 837.

${ }^{250}$ See id.

${ }^{251}$ Id. at 838.

${ }^{252}$ See id. ("Congress, under this scenario, could punish embezzlers, con artists, and muggers-even if their activity was solely intrastate-because the proceeds of the crimes likely would have helped the victim afford food, housing, medical care, or other goods and services.").

${ }^{253}$ See 18 U.S.C. $\$ 1341$ (1994).

254 See 18 U.S.C. § 1343 (1994). 
Confronted with similar government arguments, other federal district courts have found that $\$ 228$ is constitutional. Under Lopez, an activity may be regulated if it has a "substantial relation to interstate commerce" or "substantially affect[s] interstate commerce," even if the substantial effect is only the result of combining all of the individual instances of regulation under a statute..$^{255}$ The Sage court concluded that because the nonsupporting parent acquires an economic benefit from not making support payments and has more money to spend in commerce, and the child has a corresponding loss of economic benefits, there is a direct impact on the consumption of goods in interstate commerce and, thus, on the distribution of income among states. ${ }^{256}$ Even though each instance of nonsupport may not have a large effect on interstate commerce, the total unpaid support in interstate cases, about $\$ 14$ billion, would have an enormous impact on the interstate market in goods. ${ }^{257}$ In Sage, the court did not conclude that the act of nonpayment was itself an act in interstate commerce, but that these acts did have a substantial effect on interstate commerce such that they may be regulated under the logic of Wickard $v$. Filburm ${ }^{258}$ and Maryland v. Wirtz. ${ }^{259}$

The Hopper court took a slightly different approach by comparing Congress's authority to regulate the collection of child support with Congress's authority to collect other kinds of intangible obligations. ${ }^{260}$ By analogy to cases interpreting the word "commerce" in relation to the Sherman Act, ${ }^{261}$ the Hopper court held that the collection of child support is itself interstate commerce because it "involve[s] a continuous and indivisible stream of intercourse among the states involving the transmission of large sums of money and

255 United States v. Lopez, 115 S. Ct. 1624, 1629-31 (1995) (tracing the Court's decisions regarding what constitutes a substantial effect on interstate commerce).

${ }^{256}$ See United States v. Sage, 906 F. Supp. 84, 89-90 (D. Conn. 1995).

${ }^{257}$ See id. at 90 (observing that "Congress also considered noteworthy the fact that between 30 and 40 percent of all delinquent child support cases involve interstate obligations").

258317 U.S. 111, 127-28 (1942) (holding that the federal government may regulate an individual's action when "his contribution, taken together with that of many others similarly situated, [has a] far from trivial" impact on interstate commerce).

259392 U.S. 183, 196-97 n.27 (1968) (holding that the "de minimis character of individual instances arising under [a] statute is of no consequence" when the statute is substantially related to commerce).

${ }^{260}$ See United States v. Hopper, 899 F. Supp. 389, $392-93$ (S.D. Ind. 1995).
${ }^{261} 15$ U.S.C. $§ \S 1-7$ (1994) (providing criminal penalties for illegal restraints of trade). 
communications by mail, telephone and telegraph. ${ }^{262}$ Citing cases that hold that interstate fire insurance transactions, real estate brokerage, the distribution of news, and medical services to a health cooperative constitute interstate commerce, the Hopper court concluded that the collection of intangible debt for child support also constitutes commerce because it is similar to the collection of other kinds of debt regulated by Congress. ${ }^{263}$

The Murphy court employed a third line of reasoning to hold that $\$ 228$ was within Congress's authority under the Commerce Clause. Because what $\S 228$ really does is regulate the channels of interstate travel, its constitutionality should be considered in light of the line of cases that hold that Congress, within the scope of its Commerce Clause power, can criminalize activity relating to interstate travel. ${ }^{264}$ For example, Congress can make it a federal crime for a person to flee a state to avoid prosecution or for a witness to flee in order to avoid a subpoena to testify. ${ }^{265}$ Section 228 can be seen as an extension of such statutes to the specific area of child support enforcement; nonsupporting parents are often already criminals under state law and flee the state because they know that there is a slim chance of being caught if they are beyond the state's territorial jurisdiction. ${ }^{266}$ This analysis fails, however, if it is the custodial parent who has moved interstate.

On the basis of these more thorough analyses of the classification of the collection of child support debt, it seems clear that this activity meets the Lopez requirement of having a substantial effect on interstate commerce, even if the act of withholding payment is not commerce in each individual instance. Although this activity

${ }^{262}$ Hopper, 899 F. Supp. at 393 (invoking the doctrine of United States v. Shubert, 348 U.S. 222, 226 (1955)).

${ }^{263}$ See id. at 392-93.

${ }^{264}$ See United States v. Murphy, 893 F. Supp. 614, 616-17 (W.D. Va. 1995) (stating that "Lopez does not prohibit Congress from enacting laws aimed at regulating the use of interstate travel").

${ }^{265}$ See id. at 616 (citing 18 U.S.C. $\$ 1073$ (1994)); see also United States v. Toledo, 985 F.2d 1462, 1465-67 (10th Cir.) (criminalizing the common law crime of kidnapping when it involves interstate travel under 18 U.S.C. $\$ 1201$ (1994)), cert. denied, 114 S. Ct. 218 (1993); Simmons v. Zerbst, 18 F. Supp. 929, 929-30 (N.D. Ga. 1937) (affirming Congress's Commerce Clause power to punish fugitives who travel from one state to another under the Fugitive Felony Act, 18 U.S.C. $\S 408(e)$, now codified at 18 U.S.C. $\$ 1073$ (1994)); United States v. Miller, 17 F. Supp. 65, 67 (W.D. Ky. 1936) (same).

${ }^{266}$ See Weitzman, supra note 30 , at 263 (reporting survey results that show that "[t]he easiest way for a man to evade a child support order is to move to another state"). 
does not come within the traditional paradigm of commerce-the business transaction ${ }^{267}$-its effects have an impact in the billions of dollars on the ability of custodial parents and children to engage in commerce. It is also important to realize that the criminal provisions of the CSRA are a justified regulation of interstate commerce because they are one piece in a larger package of legislation regulating the economic activity of federal spending on welfare. ${ }^{268}$ Although the criminal provisions of the CSRA are not indispensable to the larger system of regulation, they promise to be a very effective tool for reaching the intrastate act of not paying child support that tremendously impacts welfare spending and interstate economies.

\section{Legislative History}

In attempting to solve the question of whether $\S 922(q)$ was constitutional, the Lopez Court also examined the statute's legislative history and concluded that there were no explicit findings that would explain Congress's presumption that there is a connection between the possession of guns near schools and interstate commerce. ${ }^{269}$ Although the Court noted that such explicit findings are not required in order for Congress to exercise its authority, it explained that, in cases of questionable legislative judgment, formal findings would help clarify Congress's reasoning. ${ }^{270}$

In contrast to the paucity of legislative history concerning interstate commerce for $\$ 922(q)$, there was a substantial amount of testimony before Congress regarding $\S 228$ of the CSRA. There were also explicit findings in the House Judiciary Committee's report that linked the failure to pay interstate child support debts to interstate commerce. ${ }^{271}$ The Sage court noted that Congress

${ }^{267}$ See United States v. Mennuti, 639 F.2d 107, 111-12 (2d Cir. 1981) (holding the federal arson statute to be inapplicable to private residences because they are not "business" property and thus are not related to interstate commerce). But see Russell v. United States, 471 U.S. 858, 861-62 (1985) (holding that the federal arson statute applied to a private home that had at one time been in the rental market because renting is an activity that affects commerce and can be regulated under the commerce clause). Following the logic of Russell, it can be argued that nonpayment of a child support debt can also be made a federal crime because the nonpaying parent would pay the debt with money earned through employment, which may be regulated under the Commerce Clause.

${ }^{269}$ Cf. United States v. Lopez, 115 S. Ct. 1624, 1631 (1995).

${ }^{269}$ See id. at 1631-32.

270 See id. at 1631.

${ }^{271}$ See H.R. REP. No. 771, 102d Cong., 2d Sess. 5-7 (1992). 
considered the inability of states to enforce their own support orders in interstate cases and found that the accumulating debt was having a substantial impact on federal and state welfare expenditures and the ability of custodial parents and children to subsist. ${ }^{272}$ The Hampshire court also discussed the Committee's report, which indicated that in 1989 alone, $\$ 5.1$ billion in child support went uncollected. ${ }^{278}$ Because $\$ 228$ would be a useful tool in collecting some of that debt, it could be expected to have a substantial effect on the national economy.

The Schroeder and Mussari courts examined the same Committee report and concluded that it offered no evidence supporting a connection between interstate commerce and the nonpayment of child support obligations. ${ }^{274}$ They conceded that the legislative history demonstrated that Congress understood the need for an interstate nexus before it could act, but they concluded that there was no evidence to show that Congress made the determination that the collection of debt was commerce. ${ }^{275}$ The courts are correct that Congress never used the word "commerce" in describing the reasons for, or the desired effects of, the legislation. Congress's actions are not invalid, however, simply because it failed to invoke a magic word; ${ }^{276}$ the report details the current difficulties in collecting interstate support in terms of its economic consequences and describes the criminal and restitutionary penalties of $\S 228$ in the larger scheme of federal involvement in interstate collection under Congress's taxing and spending powers. ${ }^{277}$ Given the pains that the Committee took in acquiring the statistics on the percentage of debt that comes from interstate cases, its approximate amount, and its dramatic effect on the economic lives of custodial

${ }^{272}$ See United States v. Sage, 906 F. Supp. 84, 90-91 (D. Conn. 1995).

${ }^{273}$ See United States v. Hampshire, 892 F. Supp. 1327, 1329-30 (D. Kan. 1995) (citing H.R. REP. No. 771, 102d Cong., 2d Sess. 5 (1992)).

${ }^{274}$ See United States v. Mussari, 894 F. Supp. 1360, 1366 (D. Ariz. 1995) (finding "no specific legislative history which would support that the CSRA is aimed at interstate commerce"); United States v. Schroeder, 894 F. Supp. 360, 367 (D. Ariz. 1995) (same).

${ }^{275}$ See Mussari, 894 F. Supp. at 1366 (finding that "[t]here is no commercial intercourse involved in the collection of delinquent child support payments"); Schroeder, 894 F. Supp. at 367 (same).

${ }^{276}$ See United States v. Lopez, 115 S. Ct. 1624, 1631 (1995) (holding that Congress need not make specific findings about the impact of proposed legislation on interstate commerce and that their failure to do so is not determinative of the statute's constitutionality).

${ }^{277}$ See H.R. REP. No. 771, 102d Cong., 2d Sess. 5-7 (1992). 
parents and children, ${ }^{278}$ it is likely the Committee members were astonished to learn that their efforts had been interpreted as having failed to discuss the substantial impact of the proposed legislation on interstate commerce.

In addition to the Committee report and the floor debate on the CSRA, Congress received many other reports detailing the enormous financial impact and the consequences of the nonpayment of support. Congress received a report from the Office of Child Support Enforcement in 1989, which indicated that of the $\$ 8.2$ billion owed in child support for the fiscal year 1989, fifty of the fifty-four U.S. jurisdictions that reported data collected only $\$ 3.9$ billion. ${ }^{279}$ Also in 1989, the total amount of support due from prior years was $\$ 15.7$ billion, but only $\$ 1.1$ billion, or seven percent, was collected nationally. ${ }^{280}$ The same report also described the necessity of federal involvement to improve the performance of state-run Title IV-D agencies. ${ }^{281}$ The U.S. Commission on Interstate Child Support's 1992 report to Congress revealed that only one dollar of every ten dollars ordered in support is actually collected in interstate cases and encouraged the development of a national computer network that would improve the availability of information about the location and income of child support obligors. ${ }^{282}$ If these unpaid amounts were collected, even partially, the resulting impact on the transfer of economic resources among states would be tremendous, drastically increasing the ability of custodial parents and children to participate in interstate commerce and dramatically reducing the amount of money spent on federal entitlement programs, which would free that money for other federal uses. As evidenced by the recent standoff over the federal budget, the allocation of federal money can exert a great deal of influence over investment and commercial markets. ${ }^{283}$

${ }^{278}$ See id.

${ }^{279}$ See OfFice of ChIld SuPport ENFORCEMENT, U.S. DEP'T OF HEALTh AND HUMAN SERVS., FOURTEENTH ANNUAL REPORT TO CONGRESS FOR THE PERIOD ENDING SEPT. 30, 1989, at 5-6 (1989).

280 See id.

${ }^{281}$ See id.

${ }^{282}$ See supra note 92 and accompanying text.

${ }^{283}$ See Gary Hoffman, Bill Roney: Get Used to Market Volatility Tied to Politics, DETROIT NEWS, Mar. 13, 1996, at B 1; Lawrence Malkin, Wall Street's Wild Days! Up, Down, All Around, INT'L Herald TRIB., Mar. 13, 1996, at 1. 


\section{Federalism and Comity}

The federal district courts' arguments about whether $\$ 228$ offends the traditional notions of federalism and comity are based on a footnote in Lopez that reaffirms that the "[s]tates possess primary authority for defining and enforcing the criminal law.' ${ }^{284}$ The note continues with a limitation on this absolute statement, however, by recognizing Congress's authority to create criminal offenses when it is acting within the scope of its delegated powers under the Constitution. ${ }^{285}$ Therefore, if the Court had concluded that $\S 922(q)$ was within Congress's authority under the Commerce Clause, the criminal nature of the regulation would not have been objectionable because the Constitution does not limit Congress to civil regulation. ${ }^{286}$

The Bailey court did not specifically hold that the regulations in $\S 228$ exceed Congress's authority under the Commerce Clause, but rather held that Congress violated the principles of federalism by involving the federal courts in an area that traditionally has been, and should continue to be, reserved to the states. ${ }^{287}$ The main objection in Bailey is that Congress has improperly involved itself in the state law of domestic relations, not that Congress has improperly created a new federal crime. ${ }^{288}$ For reasons articulated below, ${ }^{289}$ neither the Constitution nor the common law doctrines of abstention prevent Congress or the federal courts from acting to assist the collection of delinquent child support payments, and, thus, the Bailey court had no authority to act as a superlegislature and declare $\$ 228$ to be invalid simply because it does not think it was a wise policy choice. ${ }^{290}$ The Bailey court's invocation of the

${ }^{284}$ United States v. Lopez, 115 S. Ct. 1624, 1631 n.3 (1995) (quoting Brecht v. Abrahamson, 113 S. Ct. 1710, 1720 (1993) (citations omitted)).

${ }_{285}$ See id. (citing Screws v. United States, 325 U.S. 91, 109 (1945) (plurality opinion)).

${ }_{286}$ See TRIBE, supra note $62, \S 5-3$, at 301 (explaining that Congress may employ any manner of regulation when acting under its enumerated powers as long as there are no limitations on that form of regulation in other parts of the Constitution); see also Screws, 325 U.S. at 109 ("Under our federal system the administration of criminal justice rests with the States except as Congress, acting within the scope of [its] delegated powers, has created offenses against the United States.").

${ }_{287}$ See United States v. Bailey, 902 F. Supp. 727, 729 (W.D. Tex. 1995).

${ }^{283}$ See id. at 727 (describing the historical reluctance of federal courts to "becom[e] embroiled in state family matters").

${ }^{289}$ See infra part III.A.4.b.

290 See Hodel v. Indiana, 452 U.S. 314, 333 (1981) (stating that the lower court had exceeded its role by "passing on the wisdom of congressional policy determinations"); 
principles of federalism is evidence of concern about the federal government's growing involvement in areas previously managed solely by states and the consequential lack of attention paid to constitutional provisions, such as the Tenth Amendment, which may preserve an appropriate federal-state balance.

\section{a. The Tenth Amendment}

Long considered by the courts to be a "truism" with little substantive meaning, ${ }^{291}$ the Tenth Amendment was added to the Constitution to reaffirm that whereas the powers of Congress are limited, those of the states are "numerous and indefinite." 292 The Tenth Amendment provides that " $[t]$ he powers not delegated to the United States by the Constitution, nor prohibited by it to the States, are reserved to the States respectively, or to the people." 293 Although the words of the amendment would seem to imply that Congress has a very limited arena in which to act, they have not been read restrictively. While explaining the scope of the federal government's powers under the Constitution, as opposed to under the Articles of Confederation, the Supreme Court held that the Constitution does not "exclude[] incidental or implied powers," nor "require[] that everything granted ... be expressly and minutely described." 294 It found support for this statement in the fact that the Tenth Amendment omits the word "expressly" before the word "delegated." 295

Recently, the Court has attempted to infuse the Tenth Amendment with more substantive authority. The dissent in Garcia v. San Antonio Metropolitan Transit Authority ${ }^{296}$ objected that the Court's

New Orleans v. Dukes, 427 U.S. 297, 303 (1976) ("In short, the judiciary may not sit as a superlegislature to judge the wisdom or desirability of legislative policy determinations .... ."); United States v. Princeton Gamma-Tech, Inc., 31 F.3d 138, 153 (3d Cir. 1994) (Nygaard, J., concurring) (stating that it is not the court's role "to act as a superlegislature and second-guess the policy choices that Congress made").

291 See United States v. Darby, 312 U.S. 100, 123-24 (1941) (upholding the minimum wage and maximum hour requirements of the Fair Labor Standards Act over an argument that the Act violated the Tenth Amendment).

292 Gregory v. Ashcroft, 501 U.S. 452, 458 (1991) (quoting The FEDERALIST No. 45, at 292 (James Madison) (Clinton Rossiter ed., 1961)).

293 U.S. CONST. amend. X.

294 McCulloch v. Maryland, 17 U.S. (1 Wheat.) 316, 406 (1819).

295 See id. at 406-07 (detailing the differences between the "embarrassing" scope of federal power under the Articles of Confederation and that under the Constitution).

${ }_{296}^{469}$ U.S. 528 (1985) (Powell, J., dissenting). 
decision in that case "effectively reduce[d] the Tenth Amendment to meaningless rhetoric when Congress acts pursuant to the Commerce Clause." ${ }^{297}$ The dissent advocated a balancing test to determine when Congress has overstepped its Tenth Amendment bounds. ${ }^{298}$. Both Garcia and New York v. United States, ${ }^{299}$ addressed the Tenth Amendment in light of federal statutes that applied federal law to the states directly or required states to legislate directly in a particular area, as opposed to statutes that regulated private behavior. ${ }^{300}$

In New York, the Court struck down a method of congressional regulation that required the states to legislate directly, for the Court recognized that this method of regulating the states improperly interfered with the states' sovereign powers, even if Congress would have had the power to enact the desired regulation themselves. ${ }^{301}$ Neither Garcia nor New York imply that the Tenth Amendment could be the basis for declaring an otherwise constitutional exercise of Commerce Clause authority to be unconstitutional, nor do they provide support for the proposition that Congress does not have the power to regulate private activity. Section 228 regulates the behavior of private parties without interfering with state sovereignty by "commandeering" the state political or legislative processes. ${ }^{302}$ As such, $\$ 228$ should not be held unconstitutional unless it is found to exceed the boundaries of acceptable regulation under the Commerce Clause.

The Tenth Amendment protects the federal-state balance established by the Constitution. The Schroeder and Mussari courts

${ }^{297}$ Id. at 560 (Powell, J., dissenting).

${ }^{298}$ See id. at 562-63 (Powell, J., dissenting) (arguing that balancing would assess, among other factors, the indignity and injury to the states if they had to comply with federal statutes enacted under the Commerce Clause).

299505 U.S. 144 (1992).

${ }^{300}$ See id. at 159-61, 166-69; Garcia, 469 U.S. at 530-31. But see New York, 505 U.S. at 201-02 (White, J., concurring in part and dissenting in part) (finding that the distinction between statutes that regulate only states and those that also regulate private parties is unsupported by the Court's Tenth Amendment jurisprudence and arguing that ${ }^{\prime}[\mathrm{a}] \mathrm{n}$ incursion on state sovereignty hardly seems more constitutionally acceptable if the federal statute that 'commands' specific action also applies to private parties").

${ }^{301}$ See New York, 505 U.S. at 166.

${ }^{302}$ Cf. id. at 161 ("Congress may not simply 'commandee[r] the legislative processes of the States by directly compelling them to enact and enforce a federal regulatory program." (quoting Hodel v. Virginia Surface Mining \& Reclamation Ass'n, 452 U.S. 264, 288 (1981))). 
claimed that the following quote from United States $v$. Bass $^{303}$ supports their contention that $\S 228$ of the CSRA has upset this balance:

[U]nless Congress conveys its purpose clearly, it will not be deemed to have significantly changed the federal-state balance. Congress has traditionally been reluctant to define as a federal crime conduct readily denounced as criminal by the States. This congressional policy is rooted in the same concepts of American federalism that have provided the basis for judge-made doctrines .... As this Court emphasized only last Term ... we will not be quick to assume that Congress has meant to effect a significant change in the sensitive relation between federal and state criminal jurisdiction. In traditionally sensitive areas, such as legislation affecting the federal balance, the requirement of clear statement assures that the legislature has in fact faced, and intended to bring into issue, the critical matters involved in the judicial decision. ${ }^{304}$

Neither opinion, however, examines, as the excerpt demands, whether Congress specifically meant to alter the federal-state balance in the area of child support enforcement. After quoting the above language, the court in both Schroeder and Mussari moved on to the next stage of its analysis without undertaking an examination of whether Congress did face the issues involved in altering the federal balance.

Congress did, in fact, deal with the issue of superseding state criminal laws and found that such action was justified in this circumstance. The Judiciary Committee's report describes the state criminal laws that punish avoidance of child support obligations and notes that most states have adopted URESA, which provides for the extradition of child support defendants. ${ }^{305}$ But the report concludes that federal intervention is necessary because leaving interstate child support enforcement in the hands of the states has proven to be a "tedious, cumbersome and slow method of collection" and has "utterly failed to bring to justice" the most egregious cases of nonsupport. ${ }^{306}$ Additionally, as explained in Hopper, even though criminal law is generally the province of the states, there

${ }^{903} 404$ U.S. 336 (1971).

${ }^{304} I d$. at 349 (citations and footnotes omitted); see also United States v. Mussari, 894 F. Supp. 1360, 1367 (D. Ariz. 1995) (quoting this language to support its contention that $\$ 228$ of the CSRA is unconstitutional); United States v. Schroeder, 894 F. Supp. 360, 367-68 (D. Ariz. 1995) (same).

${ }^{805}$ H.R. REP. No. 771, 102d Cong., 2d Sess. 5-6 (1992).

${ }^{505}$ Id. at 6. 
exists no support for the theory put forth in Schroeder and Mussari that "principles" of federalism may be used to declare an otherwise valid act of Congress to be unconstitutional simply because the statute imposes a criminal penalty. ${ }^{307}$ The federal statute at issue in Lopez was not declared unconstitutional simply because states also had criminal statutes concerning firearm possession. ${ }^{308}$ Therefore, Lopez does not offer support for the contention in both Schroeder and Mussari that Congress may not exact a criminal rather than a civil penalty when it acts within its enumerated areas of authority.

\section{b. Federal Court Abstention in Family Law Cases}

Another one of the major underlying assumptions in the Schroeder, Mussari, and Bailey opinions is that federal involvement in family law issues, such as child support, is, at best, inappropriate. $^{309}$ Their assumptions ${ }^{310}$ are based on language in Lopez that suggests that Congress may not regulate in the area of family law by relying on its Commerce Clause authority when the only tenuous connection between the family and interstate commerce is a theory that family structures affect national productivity and that national productivity in turn affects interstate commerce. ${ }^{311}$ Contrary to the reading of the lower courts, this passage in Lopez does not stand for the proposition that all regulation of matters affecting families is prohibited under the Commerce Clause; Lopez simply requires that the regulation of family law issues have a more immediate connection to interstate commerce than an imprecise economic variable such as national productivity.

Federal courts have historically been unwilling to involve themselves in the regulation of marriage and family structure under

${ }^{307}$ See United States v. Hopper, 899 F. Supp. 389, 393 (S.D. Ind. 1995).

${ }^{308}$ See United States v. Sage, 906 F. Supp. 84, 92 (D. Conn. 1995) ("Lopez did not turn on whether a regulated activity traditionally has been the province of the states.").

${ }^{309}$ See United States v. Bailey, 902 F. Supp. 727, 728 (W.D. Tex. 1995); United States v. Mussari, 894 F. Supp. 1360, 1367 (D. Ariz. 1995); United States v. Schroeder, 894 F. Supp. 360,368 (D. Ariz. 1995).

${ }^{310}$ See Bailey, 902 F. Supp. at 728; Mussari, 894 F. Supp. at 1364 (citing Lopez's objection to government regulation of family law, $115 \mathrm{~S}$. Ct. 1624, 1632 (1995)); Schroeder, 894 F. Supp. at 365 (same).

${ }^{311}$ See United States v. Lopez, 115 S. Ct. 1624, 1661 (1995) (Breyer, J., dissenting) ("To hold this statute constitutional is not to ... hold that the Commerce Clause permits the Federal Government ... to regulate 'marriage, divorce, and child custody' ...." (quoting language used in the majority opinion by Chief Justice Rehnquist, $115 \mathrm{~S}$. Ct. at 1632)). 
the theory that these issues should be under the sole control of the states because the issues are inherently of local concern. ${ }^{312}$ Federal courts frequently would abstain from hearing cases in diversity that would otherwise be heard under their jurisdictional authority when the cases involved matters concerning domestic relations. ${ }^{313}$ The Supreme Court in Ankenbrandt $v$. Richards, ${ }^{314}$ however, explained that there were significant limits to the doctrine of federal abstention in family law cases. The Court first concluded that the Constitution does not prevent the federal courts from dealing with domestic relations issues in the exercise of diversity jurisdiction. ${ }^{315}$ The Court went on to find that the original decision to exclude certain domestic relations matters from the federal courts' jurisdiction was based upon a questionable historical construction of the diversity jurisdiction statute. ${ }^{316}$ Nonetheless, the Court held that it would not disturb that construction because Congress, through its inaction, has apparently accepted this interpretation for over a century. ${ }^{317}$

Despite its decision to uphold the validity of the general domestic relations exception to federal diversity jurisdiction, the Court found that this exception to the exercise of federal jurisdiction was limited to the original "issuance of a divorce, alimony, or child custody decree" and that federal courts had thus always been capable of enforcing the final decrees of state courts. ${ }^{318}$ If the federal courts can enforce alimony decrees with the same authority with which they can enforce other contracts, then, by analogy, there should be no bar to the federal courts' enforcement of existing child support decrees. When enforcing existing child support decrees, however, the lower courts seem particularly concerned about a

${ }^{\$ 12}$ See, e.g., Barber v. Barber, 62 U.S. (21 How.) 582, 584 (1858) (establishing the principle that federal courts have no jurisdiction over original suits for divorce or the award of alimony). The Barber Court went on to hold that the United States district courts had jurisdiction to hear a diversity suit seeking to enforce the wife's claim for court-awarded alimony against her ex-husband, who lived in a different state, and over whom the first state did not have jurisdiction. See id. at 599-600.

${ }^{313}$ See Ankenbrandt v. Richards, 504 U.S. 689, 703 (1992) (citing several federal cases as examples of this pattern).

s14 504 U.S. 689 (1992).

S15 See id. at 695 .

${ }^{316}$ See id. at $698-700$.

${ }^{317}$ See id. at 700-01.

${ }^{318}$ Id. at 704; see also Barber v. Barber, 62 U.S. (21 How.) 582, 599 (1858) (stating that the plaintiff in that case, suing for the recovery of alimony already decreed, could have brought suit in a district court of the United States). 
defendant's ability under $\S 228$ to challenge his conviction by bringing a collateral attack on the underlying support order, thus embroiling the federal courts in a substantive adjudication of custody and support issues under state law. ${ }^{319}$ It is clear that under Barber v. Barber and its progeny, such a federal role would be impermissible. ${ }^{320}$ It is far from clear, however, that such federal involvement in substantive custody and support issues would be a necessary, or even a possible, outcome of enforcement proceedings under $\S 228 .^{321}$

On a practical level, the United States Attorneys do not have the resources to prosecute every parent who refuses to pay an interstate child support obligation, or even to prosecute every case that is brought to their attention. ${ }^{322}$ As a result, the cases that the government decides to prosecute will probably be those involving the most flagrant violations of state law, such as Jeffrey Nichols's, ${ }^{323}$ or cases referred by state enforcement agencies when those agencies have reached substantial roadblocks. Therefore, although the number of federal cases that will be prosecuted under $\S 228$ will certainly increase, the federal courts will still only be involved in a very small percentage of child support cases.

More fundamentally, a defendant in a $\$ 228$ prosecution will not be able to challenge the validity of the underlying enforcement

${ }^{319}$ See United States v. Bailey, 902 F. Supp. 727, 729 (W.D. Tex. 1995) ("[E]nforcement of 18 U.S.C. $\$ 228$ invariably would open the door to abatement motions and counterclaims for change of custody or defenses based on changed circumstances .... .); United States v. Mussari, 894 F. Supp. 1360, 1367 (D. Ariz. 1995) (emphasizing the concerns expressed in Bailey); United States v. Schroeder, 894 F. Supp. 360, 368 (D. Ariz. 1995) (same).

${ }^{320}$ See In re Burrus, 136 U.S. 586, 595-97 (1890) (holding that federal courts do not have jurisdiction to issue original orders in child support cases); Barber, 62 U.S. (21 How.) at 584 (stating that federal courts lack jurisdiction "upon the subject of divorce, or for the allowance of alimony . . . as an original proceeding in chancery").

${ }^{321}$ Defendants Hopper and Hampshire contended that other federal abstention doctrines, such as those explained in Burford v. Sun Oil Co., 319 U.S. 315, 332 (1943) (holding that a federal court may refuse jurisdiction to avoid interfering with complex state regulatory policy), and Younger v. Harris, 401 U.S. 37, 54 (1971) (holding that a federal court may abstain from jurisdiction to avoid interfering with a pending state criminal prosecution), would prevent the federal courts from exercising jurisdiction over $\S 228$ cases. See United States v. Hopper, 899 F. Supp. 389, 393 (S.D. Ind. 1995); United States v. Hampshire, 892 F. Supp. 1327, 1331 (D. Kan. 1995). Neither defendant made a strong case for abstention.

${ }^{322}$ See Deadbeat Dad Enforcement, supra note 186, at 2 (discussing the criticism received by the Justice Department for its lax enforcement of the CSRA and the resulting 1995 campaign of increased prosecution under that law).

${ }^{923}$ See supra notes 1-14 and accompanying text. 
order because the past-due amount is not modifiable once a state court has entered a final judgment on it. ${ }^{324}$ Therefore, the only potential challenge to the underlying order would be a prospective challenge, which would have to be made in the state that has continuing exclusive jurisdiction over the support order. ${ }^{325} \mathrm{~A}$ federal court would almost certainly decline to exercise pendent jurisdiction $^{326}$ over that claim and would dismiss the claim in anticipation of an appropriate state suit. The resulting state proceeding would not affect the outcome of the federal proceeding because it would be concerned with a different period of time.

The Bailey court contends that a federal court, in implementing the restitutionary provisions of $\S 228$, would inevitably become "embroiled in state family law matters." ${ }^{327}$ As a result of having to determine a defendant's ability to comply with a state support order because "[the court] would not convict a non-paying parent who, subsequent to divorce, had become quadriplegic," the court would necessarily "open the door to abatement motions and counterclaims for changes of custody. ${ }^{\text {n28 }}$

There are two responses to this concern. First, it has not been demonstrated, either by the Bailey court or elsewhere, that federal courts are incapable of determining the ability of a defendant to pay restitution and determining reasonable payment schedules; this task does not invoke state domestic relations law and is not beyond the expertise of federal judges, who often impose fines as parts of criminal sentences. ${ }^{329}$ Second, the Bailey court seems to be afraid that the "ability to pay" issue will expand and generate counterclaims based on substantive domestic relations law. ${ }^{330}$ In reality, the ability to pay analysis is much narrower. It asks only whether the defendant has willfully failed to pay support obligations. ${ }^{331}$ As

${ }^{324}$ See MELLI ET AL., supra note 152, at 18-62.

${ }^{325}$ See supra part II.A.3.c (discussing the limited ability of states to modify existing orders under UIFSA).

${ }^{326}$ A modification proceeding would involve the federal courts in the establishment of an original child support order, an action that would be contrary to the doctrine of Ankenbrandt v. Richards, 504 U.S. 689, 694-95 (1992) (recognizing a domestic relations exception to federal diversity jurisdiction).

${ }^{327}$ United States v. Bailey, 902 F. Supp. 727, 729 (W.D. Tex. 1995).

${ }^{328} I d$. at 729.

${ }^{329}$ See U.S. Sentencinc GuIDELINES § 5E1.2 (1996) (requiring judges to impose fines on all defendants able to pay them).

${ }^{330}$ See Bailey, 902 F. Supp. at 729.

331 See 18 U.S.C. $\$ 228(a)$ (1994) (limiting the section's coverage to individuals who "willfully fail[]" to pay child support). 
the legislative history of the CSRA reveals, willfulness is a standard borrowed from the Federal Tax Code's crime of willful failure to collect or pay tax obligations, and a successful tax prosecution requires the government to "establish, beyond a reasonable doubt, that at the time payment was due the taxpayer possessed sufficient funds to enable him to meet his obligation or that the lack of sufficient funds on such date was created by (or was the result of) a voluntary and intentional act without justification.'n332 Thus, a quadriplegic defendant who could not support himself would not be found to have "willfully" failed to pay child support, unless he was quite wealthy. Also, this analysis leaves no room for counterclaims.

For the reasons discussed above, it is clear that the criminal provisions of the CSRA, as a constitutional matter, do not upset the federal-state balance established by the Tenth Amendment and federal abstention doctrine. Many critics have argued, however, that Congress should not enact federal criminal legislation, such as $\S 228$ of the CSRA, as a matter of policy.

\section{B. The Federalization of Crime and Its Critics}

As Congress continues to expand the scope of federal criminal law by creating new federal crimes, many scholars and judges have argued that the federalization of crime violates principles of federalism and results in the misuse of federal judicial resources. Federal criminal filings increased by approximately seventy percent during the $1980 \mathrm{~s},{ }^{333}$ and some judges worry that the resulting increased caseload will create clogged dockets, which will inevitably reduce the quality of the federal judiciary's work. ${ }^{334}$ For a number of reasons, the primary concern of commentators seems to be the creation of federal criminal laws that mirror laws already in place in the states. ${ }^{35}$ There is a general belief that these

${ }^{392}$ H.R. REP. NO. 771, 102d Cong., 2d Sess. 6 (1992) (quoting United States v. Poll, 521 F.2d 329, 333 (9th Cir. 1975)).

${ }^{333}$ See Stephen Chippendale, Note, More Harm Than Good: Assessing Federalization of Criminal Law, 79 MINN. L. REv. 455, 456 (1994) (advocating that Congress appoint a commission to discourage the creation of new federal criminal statutes).

${ }^{334}$ See William P. Marshall, Federalization: A Critical Overview, 44 DEPAUL L. REv. 719, 719 (1995) (citing a 1993 letter from Ninth Circuit Chief Judge J. Clifford Wallace, who emphasized this concern to Chief Justice William Rehnquist, Attorney General Janet Reno, and others). But see Rory K. Little, Myths and Principles of Federalization, 46 HASTINGS L.J. 1029, 1038-47 (1995) (addressing the "myth" that federal courts' time is so monopolized by criminal cases that important civil cases are pushed aside).

${ }^{395}$ See Marshall, supra note 334 , at 720 (warning that "federalization may directly 
duplicative laws not only create a waste of judicial and prosecutorial resources but also usurp each state's authority to declare the appropriate punishment for a crime. ${ }^{336}$ Because the Federal Sentencing Guidelines set rather severe mandatory minimum sentences for certain categories of crimes, the federal penalties are often harsher than the state penalties for the same action. ${ }^{337}$ Furthermore, the uncertainty of which punishment, state or federal, should apply raises due process concerns when similarly situated offenders are punished differently and lessens the deterrent effect of the more stringent federal penalty. ${ }^{338}$ Also, because federal prosecutions occur in such a small percentage of eligible cases, some commentators have expressed concern that there may be bias in the way federal cases are selected and, also, that such a small intrusion into an area otherwise controlled by states is not worth the cost to the principles of federalism. ${ }^{339}$

In analyzing solutions to these problems, most commentators admit that the drive to federalize crimes must be stopped by Congress or by the prosecutorial policies of the Department of Justice because, given the expansive nature of most Commerce Clause interpretations, the federal courts will probably be unable, or at least extremely unwilling, to find a majority of these statutes

impinge upon individual rights as the creation of federal crimes paralleling state offenses perils the protections for the individual found in the Double Jeopardy Clause"); H. Scott Wallace, When More Is Less: The Drive to Federalize Is a Road to Ruin, CRIM.JuST., Fall 1993, at 8, 52 (lamenting that "Congress is now in the business of creating massive disparities between federal and state penalties for the same conduct"); Chippendale, supra note 333, at $461-62$ (noting that "[o]ver the last two decades Congress has transformed federal law enforcement by enacting a determinate sentencing scheme, mandatory sentencing statutes, and criminal statutes that essentially duplicate state codes" (footnotes omitted)).

${ }^{396}$ See Sara S. Beale, Too Many and Yet Too Few: New Principles to Define the Proper Limits for Federal Criminal Jurisdiction, 46 HASTINGS L.J. 979, 981-82 (1995) (contending that "there are sound reasons for the states rather than the federal government to play the leading role in general criminal enforcement ${ }^{n}$ ).

${ }^{397}$ See Wallace, supra note 335 , at 50 (discussing federal death penalties that apply in some drug cases, even when the criminal activity does not directly involve interstate travel, and the state in which the activity occurred does not have the death penalty).

${ }^{358}$ See Beale, supra note 336, at 997-1001 (arguing that "structural inequalities" occur when state and federal courts produce different results in similar cases and that, as a practical matter, federal prosecutors do not have sufficient resources to supplant state criminal jurisdiction completely in the areas where the federal and state governments have concurrent jurisdiction).

${ }^{3 s 9}$ See Wallace, supra note 335, at 52-53 (arguing that the extreme arbitrariness of federal prosecutions is unfair to individual defendants and weakens the potential deterrent effect of criminal laws and, therefore, that the federalization of crime does not produce benefits that justify distorting the federal-state balance). 
unconstitutional. ${ }^{340}$ The result in Lopez is held out as hope that federal courts will begin to restrict the extent of permissible regulation under the Commerce Clause, the power behind most new federal criminal law. ${ }^{341}$ The major problem in respecting the borders of federalism, these authors conclude, lies in the development of a principled way to distinguish those areas in which a federal criminal statute is appropriate from those in which it is not. ${ }^{342}$ Although the imposition of federal criminal sanctions for violations of child support orders is new, it is important to note that federal courts, when acting under diversity jurisdiction, have always been able to enforce the final and unmodifiable judgments of state courts for amounts of overdue child support. ${ }^{343}$ Thus, while Congress has given the federal courts a new type of sanction for the failure to pay child support in the form of $\S 228$, it has not granted the federal courts a completely new area of jurisdiction.

Several attempts have been made to define the principles of federalism. One suggestion, made over twenty years ago by the National Commission on Reform of Federal Criminal Laws, is to limit federal jurisdiction to cases that involve a substantial federal interest. ${ }^{344}$ As pointed out by other commentators, however, the problem with a standard that conditions federal action on a crime's

${ }^{540}$ See Thomas M. Mengler, The Sad Refrain of Tough on Crime: Some Thoughts on Saving the Federal Judiciary from the Federalization of State Crime, 43 U. KAN. L. REV. 503, 529-30 (1995) (arguing that legislators have unnecessarily involved federal resources in crimes of local importance in an effort to show that they are taking a tough stance on crime prevention); Chippendale, supra note 333, at 474 (claiming that there are "serious drawbacks" involved in asking either the judiciary or the executive branch to limit the federalization of crime and that Congress is in the best position to impose limitations upon itself).

${ }^{311}$ See Marshall, supra note 334, at 725-26 (expressing, although with considerable doubt, that Lopez could be the first step toward the Supreme Court's eventual imposition of "significant constitutional limitation on the reach of Congressional power"); Ronald A. Giller, Note, Federal Gun Control in the United States: Revival of the Tenth Amendment, 10 ST. JOHN's J. LEGAL COMMENT. 151, 164-66, 169 (1994) (discussing the decision of the circuit court in Lopez and expressing hope that the Supreme Court would provide needed guidance on defining the necessary connection between federal gun statutes and interstate commerce).

${ }^{342}$ See Little, supra note 334, at 1072 ("The present question, then, is what principles should govern federalization of dual jurisdiction criminal conduct.").

${ }^{343}$ See Ankenbrandt v. Richards, 504 U.S. 689, 701-02 (1992) (noting that, while federal courts have historically lacked the power to grant a divorce or alimony decree, federal courts have always had jurisdiction to enforce properly obtained decrees); see also supra notes 314-18 and accompanying text (elaborating on Ankenbrandl's statement that past cases did not intend to prevent federal courts from hearing any case involving any domestic relations matter).

s4t See Wallace, supra note 335 , at 55. 
"importance" may easily lead to the expansion rather than the retraction of criminal statutes because of the significant pressure on legislators to consider the causes of all special interest groups to be "important." 1455 This pressure on legislators is likely to be especially strong when the problem is national in scope and is a subject of current concern. ${ }^{346}$

Another proposed standard judges the propriety of federal involvement by asking whether the states have "demonstrated failure" in their attempts to enforce the criminal laws in question. ${ }^{347}$ In other words, if the effectiveness of state enforcement is limited by the multistate aspects of the case and the conduct involved is serious, a factor perhaps judged by the amount of money involved, then it would be appropriate for the federal government to exercise jurisdiction. ${ }^{348}$ Applying this standard to the CSRA, it is clear that enforcement of $\S 228$ is an area where federal criminal jurisdiction is appropriate. The multistate nature of the transactions prevents states from effectively reaching those whom they wish to prosecute, and the process of extradition is often slow and ineffective in these cases. ${ }^{349}$

Another articulation of the standard would require proof, even when the states' authorities agree that federal assistance is necessary, that the states' enforcement efforts had, in fact, been ineffective. ${ }^{350}$ Such proof could consist of evidence of violations that have gone unprosecuted, the amount of state resources that have been unsuccessfully devoted to enforcement, and the adverse effects that nonenforcement is having on the public interest. ${ }^{351}$ Again, this proof could be marshalled to support federal involvement under the CSRA. As evidenced by the cases of Jeffrey Nichols $s^{352}$ and others, flagrant violations of state law frequently went unpun-

${ }^{345}$ See Marshall, supra note 334, at 734-35 (enumerating the problems inherent when considering "importance" as the pivotal factor upon which to decide whether or not to federalize).

${ }^{346}$ See id.

${ }^{377}$ See Little, supra note 334, at 1078-81 (discussing the concept and application of a "demonstrated state failure" standard); Mengler, supra note 340, at 526 (recommending federal jurisdiction where the "conduct is serious ... and state enforcement is impeded by the multistate or international aspects of the case").

${ }^{348}$ See Mengler, supra note 340 , at 526.

${ }^{349}$ See supra notes $101-03$ and accompanying text.

${ }^{350}$ See Little, supra note 334, at 1078-79.

${ }^{351} \mathrm{See}$ id. at 1080 (emphasizing the importance of requiring actual "demonstration" in any effective version of the "demonstrated state failure" standard).

352 See supra notes 1-14 and accompanying text. 
ished until federal enforcement resources were used. The demand for more state expenditures to meet the increasing burden of interstate cases is also evidence that the state enforcement systems are currently overwhelmed; the average caseworker only has time to spend eight minutes per month on each case, and in such a hectic environment, caseworkers become "customer driven," spending their limited available time pursuing only the few cases concerning which there is outside pressure. ${ }^{353}$ Moreover, it is undeniable that the failure to obtain child support has an adverse effect on the millions of children and custodial parents who may be left with insufficient financial resources.

Another criticism leveled at the criminal provisions of the CSRA is that criminal penalties are inappropriate for the failure to pay debts and that there is no justifiable reason to treat child support obligees differently from commercial obligees. ${ }^{354}$ Although there is no ironclad answer to this concern, it is reasonable to assume that the risks of commercial nonpayment are figured into the costs of commercial credit and that the risk of loss is a factor considered in the normal course of business. Conversely, there is no way for a child support obligee to guard against the risk of nonpayment. Therefore, the nonpayment of child support is a more serious and potentially devastating problem than is the nonpayment of commercial obligations. It could also be argued that criminal penalties are punishing the failure to comply with the court's child support order and not the failure to pay a personal debt. ${ }^{355}$

It is questionable whether federal criminal enforcement will be able to increase the percentage of child support orders that are actually paid when state criminal enforcement has failed to do so. It is important to realize that many of the failures associated with state criminal enforcement have resulted from the states' lack of extraterritorial jurisdiction and the low priority given to requests for extradition in those cases. ${ }^{356}$ In contrast, territorial jurisdiction

${ }^{35 s}$ See Calhoun, supra note 31, at 941 (citing the statement of a program specialist from the Virginia Division of Child Enforcement, who reported that caseworkers are so overburdened that if they were actively to pursue every one of their cases, they would be able to allot only minimal time to each case per month and that caseworkers, therefore, only spend significant and meaningful time on a small number of cases).

${ }^{354}$ See MELLI ET AL., supra note 152, at 15-44 to 15-45 (finding that "the constitutional argument that [the] use of contempt [of court] violates [state] prohibitions against imprisonment for debt has largely been unsuccessful").

${ }^{355}$ See, e.g., Ensley v. Ensley, 238 S.E.2d 920, 922 (Ga. 1977).

${ }^{356}$ See Lewis, supra note 5, at 29A; see also supra note 266 and accompanying text 
will not be able to defeat federal enforcement efforts. Moreover, the deterrent effects of simply having the federal criminal law will probably be substantial because criminal convictions carry a much more severe social stigma than do civil contempt orders. ${ }^{357}$ Law enforcement officials are also likely to act more quickly on a criminal case than on a civil matter. ${ }^{358}$ The threat of criminal prosecution can act prospectively to deter those who have yet to fall behind in support payments and can, thus, reduce the number of enforcement cases in the future, especially when those cases that are prosecuted by the Justice Department receive a great deal of public attention. ${ }^{359}$ Finally, the federal statute allows the courts to order restitution, so the obligation can be recovered in the same proceeding that imposes a criminal sanction. ${ }^{360}$

\section{CONCLUSION}

Based on the foregoing analysis, it is clear that the decisions in Schroeder, Mussari, Parker, and Bailey are wrong as matters of both constitutional law and policy. The limitations on Congress's authority to enact legislation under the Commerce Clause, which were described in Lopez, are not exceeded by the criminal provisions of the CSRA. Section 228 includes a specific jurisdictional limit on federal authority, deals with an activity having a substantial impact on the national economy, addresses the issue of interstate commerce in its legislative history, and does not violate the principles of federalism. Also, as a question of policy, interstate child support enforcement can be greatly aided by federal involvement. With regard to federalism, it would be hard to claim that the federal government usurps any of the states' powers when it merely acts to provide additional resources and remedies that will benefit the

(describing the ease with which nonsupporting parents can flee the state to avoid child support enforcement).

${ }^{957}$ When Michigan had a strict policy of jailing nonsupporting parents, compliance rates increased for both parents who had been previously jailed and those who had never been incarcerated. See David L. Chambers, Men Who Know They Are Watched: Some Benefits and Costs of Jailing for Nonpayment of Support, 75 MICH. L. REV. 900, 921 (1977).

${ }^{358}$ See Calhoun, supra note 31 , at $938-39$.

${ }^{359}$ See WEITZMAN, supra note 152, at 299 (arguing that a high probability of a jail sentence is a very effective deterrent); Deadbeat Dad Enforcement, supra note 186, at 2 (describing the Justice Department's 1995 media-supported campaign that attempted to recover almost $\$ 1$ million from $\$ 228$ violators in 28 cases in 13 states).

${ }^{360}$ See 18 U.S.C. $\$ 228(c)(1994)$. 
citizens of the states and will add strength to state courts' judgments by allowing them to be more easily enforced, and, thus more meaningful. 